\title{
EL CLERO CUBANO Y SU PARTICIPACION \\ EN LA ENSEÑANZA PRIMARIA (1800-1868)
}

\section{A) Características generales}

Como bien dice Ismael Teste, el primer maestro que tuvo Cuba fue al mismo tiempo su primer sacerdote; ${ }^{1}$ pero esta afirmación la debemos someter a un mínimo análisis. Efectivamente, hasta el siglo XVIII, en que el objetivo principal y a veces único de la enseñanza era la doctrina cristiana, educación y clero fueron dos términos en estrecha relación; tal vez por esta razón el espíritu de caridad haya presidido la labor educativa incluso hasta nuestros días, y también ha destacado más el elemento vocacional que el profesional en el ejercicio del magisterio. La Ilustración señaló como fin del proceso educativo no ya la salvación del individuo, sino la perfección del hombre en la tierra mediante el mejoramiento de sus condiciones económicas y sociales; es decir, como afirma Dorothy Tanck Estrada, la esperanza estaba puesta en el progreso más que en Dios. ${ }^{2}$

Las Cortes de Cádiz añadieron a las ideas ilustradas nuevos conceptos democráticos que hicieron variar la concepción de la enseñanza religiosa. Durante el siglo XIX las notables diferencias entre los gobiernos absolutistas y liberales primeros, así como entre modernos y progresistas después, unidos a la fe de los liberales en que por la vía de la educación se podrían conseguir buenos ciudadanos, fueron causas que justificaron hechos tan extremos como delegar el Estado en la Iglesia todo el peso de la enseñanza pública gratuita, a prescindir de las órdenes religiosas y aumentar la participación del Estado en la educación, mediante el control de pág. 79.

1 Teste, Ismael: Historia Eclesiástica de Cuba. Barcelona, 1975, tomo V,

2 Tanck Estrada, Dorothy: La educación ilustrada (1786-1836). México, 1977, pág. 5. 
las escuelas por parte de ayuntamientos y de una inspección central.

Pero dejemos las ideas generales para centrarnos sobre la enseñanza de los religiosos en la isla de Cuba. Es un hecho evidente que cuando los ayuntamientos cubanos, en nombre y representación de sus respectivas poblaciones, solicitaban la instalación en su municipio de determinadas órdenes religiosas, lo hacían pensando - sobre todo y ante todo- en que impartieran enseñanza: franciscanos, dominicos, betlemitas, ursulinas..., en La Habana, Santiago de Cuba, Puerto Rico o Bayamo, por citar algunas localidades, como ya veremos más adelante, su instalación fue condicionada a que se dedicaran al ejercicio de la docencia. Cuando alguna de estas órdenes se niegue a cumplir con la labor educativa, no tendrán inconveniente en recordarles el origen y causa de su fundación; así, por ejemplo, en 1804, la Justicia y Ayuntamiento de Guanabacoa escribía a la Corona que el motivo que tuvieron los vecinos de dicha villa para recibir en su población a los religiosos de San Francisco fue el que atendiesen a la educación de sus hijos, como así lo acreditaba una cláusula de la real cédula de su fundación de 19 de diciembre de 1721. El prelado de dicha orden interpretaba que se debía entender por ella la instrucción en la doctrina cristiana, negando a sus subordinados (los franciscanos) que se dedicasen a la enseñanza, por considerarla incompatible con su estado de recogimiento y abstracción. La opinión del Consejo de Indias, en este problema, fue que debían atender a la instrucción de los pueblos que los alimentaban, que aunque no fuera compatible con el estado de meditación debería preferirse e: ejercicio como el de mayor mérito en el orden de la caridad porque

"...el que se dedica a la vida contemplativa trabaja sólo para sí; pero el que a ésta une la activa trabaja para sí y sus semejantes, en lo que sin duda se encuentra mayor perfección".

Del expediente sobre la docencia en Guanabacoa podemos sacar sabrosas conclusiones por las consultas y opiniones que se barajaron en el Consejo. La utilidad de la enseñanza de las primeras 
letras - dicen - es evidente, y la justifican porque es imprescindible para adquirir conocimientos de la religión. ¿Es conveniente el estudio de filosofía y teología? —se preguntan en segundo lugar-. Aunque no tan necesario como las primeras letras -contestan-, es indispensable para los que se dediquen a la carrera de las letras. Reconocen que a veces se ha mirado como perjudicial a los intereses del Estado el que demasiado número de personas se aplicasen «al estudio de las ciencias por distraerlos de otras ocupaciones útiles»; pero justificaban su enseñanza con una nueva pregunta: ¿Cómo ha de ser maestro el que no ha estudiado? para concluir dando carta de naturaleza a la participación de los religiosos en la docencia al afirmar que

"La experiencia constante de que de la instrucción del clero se deriva la instrucción pública... es la que dio lugar al establecimiento de los seminarios conciliares...».

En tercer lugar se preguntaban:

“¿Convendría utilizar en la enseñanza a los religiosos moradores en sus conventos, aun cuando no estén obligados por leyes de justicia?».

Esta cuestión es sencilla —opinaban-, pues

"La Ley de Indias que manda se edifiquen monasterios donde sean necesarios para la enseñanza de los naturales no tuvo por objeto la precisa de las verdades de la Religión... en las Misiones no se limitaban a instruir a su grey en las verdades de la Religión... los principios de orden, ideas de cultura, policía, conocimiento de las artes y oficios, la de la economía doméstica y los intereses de la agricultura, todo entraba en su plan...). ${ }^{3}$

3 A.G.I., Ultramar, 13. Expediente sobre primeras letras en Guanabacoa. Madrid, 14 de abril de 1804. Christóbal Gómez, en virtud de poder, la Justicia y Ayuntamiento de la villa de Guanabacoa exponían al Consejo, con cuatro testimonios," la decadencia y falta de educación pública.

Tomo XLVIII

31.-Anuario 
Desde Madrid no sólo contemplaban como útil la participación de los religiosos en la enseñanza, sino que les facilitaban todo an programa de actuación educativa, siempre y cuando se consider:asen como misioneros permanentes.

No tenían inconveniente las autoridades de la Corte en elogiar la labor educativa de cualquier religioso porque - decíanhabía de ser más fructuosa que la de cualquier secular:

"Ellos, por lo común, deben tener mayor instrucción, su conducta se observa más de cerca por los superiores; y como están más acostumbrados al orden y a la disciplina deben ser más arreglados en su conducta y costumbresw. ${ }^{4}$

Pero en esa alabanza se trataba de una exposición de deseos más que de justificar una serie de conductas. Vamos al dedicar unas líneas, a continuación, a analizar las cualidades del clero de la isla cubana para sacar posibles conclusiones de su repercusión en la enseñanza.

En cuanto a vocaciones religiosas el primer problema ciue se nos presenta es el de su escasez en aquel territorio. Ismael Teste nos plantea el círculo vicioso que se ha querido encontrar en torno a esta materia: «no hay vocaciones porque no hay instrucción religiosa y no hay instrucción religiosa porque no hay vocaciones». ${ }^{5}$ Sea por lo que fuere, la realidad es que a pesar de funcionar dos seminarios, el de San Carlos en La Habana y el de San Basilio en Santiago de Cuba, apenas proporcionaban clérigos para cubrir las vacantes de los religiosos seculares; en cuanto a los regulares, en su inmensa mayoría, eran procedentes de España.

4 Ibídem.

5 Tesie, Ismael: Historia eclesiástica..., tomo V, págs. 200-202. Alega Teste que sí que ha habido vocaciones religiosas pero plantea una serie de interrogantes de el porqué no ha habido más:

A) ¿Se ha pedido al Señor con la debida insistencia?

B) ¿Han dado los operarios el ejemplo que necesitaban?

C) ¿Fueron y son nuestros seminarios verdaderos semilleros de ciencia y virtud? ¿Han estado al frente de ellos los mejores sacerdotes?

Termina dando una posible justificación de el porqué han elegido pocos la carrera sacerdotal.

D) Las ventajas materiales han podido mover a estudiar otras carreras. 
Con respecto a los seminarios, el de La Habana gozaba de buen prestigio, contaba con cátedras bien dotadas económicamente y por sus aulas pasaron profesores y alumnos distinguidos: Félix Varela, Luz y Caballero, José Antonio Saco..., personajes que, si bien es cierto, para los cubanos representan su orgullo personal, mirado este asunto desde Madrid, igual que ocurría con la Universidad de La Habana, el seminario, podía considerarse, en determinados momentos $\mathrm{y}$ en señaladas cátedras, como foco de movimientos independentistas $\mathrm{y}$, por tanto, opuesto a los intereses coloniales de España.

Contrariamente a lo que pasaba en La Habana, en el seminario de Santiago de Cuba casi todo era negativo. Establecido en 1772, por el obispo Jerónimo Valdés, a finales del siglo XVIII, incluso llegó a cerrar sus puertas por falta de medios económicos. En 1794 se quejaba el obispo, Joaquín de Oses, de

“La falta de estudios públicos, de buenos principios, pésimo método de estudiar y un desarreglado Colegio Seminario ha ocasionado bastante ignorancia, a que, como a madre de todos los errores le han sucedido la indisciplina y detestables abusos que me infligieron el corazón; pero me lo consuelan la común docilidad de todos, no menos que la reforma que se advierte ya en el clero....). ${ }^{6}$

Pero ni clero ni seminario mejoraron cuando, en 1816, el gobernador de la ciudad, Eusebio Escudero, en la introducción de los Estatutos de dicha institución, que remitía a la Corona, informaba:

«...en lugar de Colegio hallamos una casa tan desmantelada que no podría habilitarla un padre de familia tranquilamente... sin fortaleza en sus fábricas, sin distribución en sus oficinas y sin orden en nada. Carecen de aulas las enseñanzas, son unos calabozos; los aposentos de los jóvenes, faltos de muebles y decencia... No podía haber policía, disciplina, ni instrucción en un lugar de tan feas apariencias...).

6 A.G.I. Santo Domingo, 2.2£9. Joaquin Oses a Eugenio de Llaguno. Cuba, 19) de diciembre de 1794. 
Sobre los estudios que se practicaban en dicho Seminario, decía:

«...La Sagrada Liturgia, la Escritura, los Santos Padres, la Teología Escolástica y lugares comunes de sus argumentos, que son propiamente las disciplinas eclesiásticas de que el concilio desea imbuir a los que se eduquen en sus seminarios... no habían tocado aún a la puerta del nuestro y el Moral y los Cánones ceñidos; el primero a una lección semanaria y los segundos a un maestro, ya se ven el progreso que podían tener...».

Con respecto al número de seminaristas, sobre los doce de la primera dotación dice el gobernador haberse aumentado en seis «a reserva de completar 24»; es decir, tan sólo contaba con 18 seminaristas. $^{7}$

¿Cómo era el clero que llegaba a Cuba procedente de España? Si nos guiamos por la información facilitada por Ismael Teste dejaba bastante que desear

«...y si bien es cierto que los hubo buenísimos y en extremo sacrificado, no es menos cierto que otros, aunque no eran presidiarios, salieron de España en busca de fortuna, y la gran facilidad con la que los obispos les dejaban salir demuestra que se quitaban al marcharse ellos un gran dolor de cabeza de encima). ${ }^{8}$

Numerosos documentos encontrados en los archivos avalan la opinión de Teste. Todavía sin finalizar el siglo XVIII -1787-, en una visita que realiza el obispo de Cuba al hospital de San Juan de Dios de La Habana, y que incluimos aquí porque muchos de los defectos que encuentra pasaron al siguiente siglo, cuenta al rey, en un extenso documento del que resumimos lo que consideramos más importante, que ha advertido: desórdenes en la administración de sus temporalidades; abandono en la curación

7 A.G.I., Santo Domingo, E.214. Informe del gobernador. Eusebio Escudero al ministro de Gracia y Justicia. Cuba, 6 de julio de 1816. Constan los Estatutos de dicho Colegio Seminario.

8 Teste, J.: Historia eclesiástica..., tomo V, pág. 199. 
de los enfermos, principal misión de estos regulares; abandono en la vida interior de los clérigos, no hay oración ni ha habido hasta ahora refectorio, muchos de ellos comen en sus casas, y toman el alimento en monedas, tienen propio peculio, y hasta fincas, «sin que conste en el archivo porque éste es imaginario»; el hospital es albergue de juegos de envite «y alguno de sus miembros ha tenido aliento de ser administrador de una casa pública de éstos»; viven algunos «extraclaustra» y hasta ha llegado el caso de pasar enfermedades en casa de sus «barraganas»; salen solos de día y algunos de noche en trajes seculares; en fin, no tienen otro acto religioso que la asistencia a las enfermerías... «a que no concurren siempre». El prelado concluye diciendo: «estos desórdenes exigen reforma... y que se reduzcan estos religiosos al contenido de la ley $\mathrm{V}$ tít. $.^{\circ} 4 .^{\circ}$, lib. $1 .^{\circ}$ de las recopilaciones de estos reinos...». ${ }^{9}$

La llegada de Juan José Díaz de la Espada, hombre enérgico, al obispado de La Habana, en 1802, supuso muchos e importantes cambios en la vida del clero. El expediente sobre la visita que realizó por su diócesis, durante 1803, 1804 y 1805, es un interesantísimo documento porque hace un relato de cómo se encontraba la Iglesia en la isla a comienzos del XIX. Acusa, el prelado, a muchos eclesiásticos de sus vidas y costumbres. Igualmente censura al arzobispo de Cuba por proteger a todos aquellos que él acusaba, sin guardar orden, ni forma de derecho, usurpándole su jurisdicción al excederse en los límites de la propia. ${ }^{10}$

Franciscanos, dominicos, capuchinos, betlemitas, agustinos..., todos se quejaban de los procedimientos adoptados por el obispo

9 A.G.I., IUtramar, 116. El obispo de Cuba, electo de La Puebla de los Angeles, da cuenta a V. M. de la visita que ha hecho del hospital de San Juan de Dios de La Habana. La Habana, 15 de diciembre de 1787 . Una reall cédula de 13 de diciembre de 1790 encargaba al obispo. Felipe José Trespalacios, que remediara el desorden en el convento hospital de San Juan de Dios. El 22 de diciembre de 1791. Trespalacios remitía a la Corona testimonio de las diligencias efectuadas, al tiempo que proponía medios para mejorar dicha institución.

10 A.G.I., Ultramar, 395. Expediente sobre la visita del obispo Espada practicada en su diócesis. La Habana, 23 de mayo de 1807.

El prelado aprovecha su viaje para revisar libros parroquiales, utensilios sagrados, altares, sacristías, hospitales; busca lugares idóneos para establecer los cementerios; a sus expensas propaga la vacuna... 
Espada, por las vejaciones que causaba a los religiosos de sús, órdenes. ${ }^{11}$ Tal cúmulo de documentos, contrarios al diocesano, llegaron a la Corte que, fiscal y Consejo de Indias, propusieron al monarca, en 1817, como así ordenó, que se mandara a aquel prelado que tratara a dichos religiosos con la suavidad que le estaba prevenida. ${ }^{12}$

Anteriormente, el 14 de abril de 1815, contestando al Ministerio Universal de Indias sobre las denuncias que había hecho el vicario provincial de las dos Castillas de los capuchinos, el obispo de La Habana decía no hacer otra cosa que cumplir con su deber; que se había tratado de disponer el ánimo del rey contra él con quejas infundadas, en parte inciertas y en parte silenciando las causas y circunstancias por las cuales había dado aquellas disposiciones generales y gubernativas en la diócesis. Aprovechaba la ocasión para exponer: ante la Corte:

“Los abusos e inconvenientes que resultaban de las repetidas y largas mansiones de los regulares en los campos y pueblos cercanos, que llegan regulares de otros obispados sin licencia, sin contar para nada con él..., la falta de disciplina monástica, la falta de observancia de la vida claustral...). ${ }^{13}$

No sólo el obispo se lamentaba de la falta de disciplina de los religiosos. En carta remitida a la Corte, por el gobernador de La Habana, el 7 de noviembre de 1803, exponía la conducta rela-

11 A.G.I., Santo Domingo, 2.236. Nicolás de Herrera y otros seis presbíteros más se quejan de su prelado. La Habana, 10 de diciembre de 1802.

A.G.I., Ultramar, 370 y 371 . En estos dos legajos abundan los documentos, en especial de los capuchinos en los que se quejan de la actuación del obispo Espada, fundamentalmente durante los años de 1814, 1815 y 1816, es decir, cuando habia vuelto Fernando VII al absolutismo.

A.G.I., Ultramar, 372. Fray Juan de Buenaventura, el 18 de agosto de 1816, también se lamentaba de que el obispo de La Habana, para explorar el ánimo de las novicias del convento de Santa Clara, les hacía salir del claustro secularizadas.

12 A.G.I., Ultramar, 3. Consejo de 20 de mayo de 1817.

13 A.G.I., Ultramar, 370. El obispo de La Habana al ministerio Universal de Indias. La Habana, 14 de abril de 1815. Era contestación de una real orden, de 17 de noviembre de 1814, sobre las quejas dadas por el vicario general de los capuchinos... 
jada que se observaba en muchos de los franciscanos, concretamente, que iban de la península, expresando que, para ser así, convendría más no enviar ninguno. El Consejo, en pleno de dos salas, «después de madura reflexión», reconocía que aunque por las leyes y demás disposiciones se hallaban prevenidas las buenas cualidades que debían adornar a los religiosos que se colectasen para las misiones de Indias, pasaban no obstante a ellas muchos que en lugar de edificar destruían y escandalizaban con su ejemplo. Entre las causas de este gravísimo mal, decían encontrarse: la fragilidad humana, la negligencia de los comisarios generales y

«... principalmente en la aversión con que miran los provinciales y prelados locales de España estas colectaciones dando informes engañosos a los colectadores para retener a los religiosos que son de vida y costumbres probadas y descartar de sus conventos a los díscolos y relajados... Si en todos los colectados pudiera verse su corazón se hallaría que van impelidos o de un disgusto con sus superiores o de un tedio de la vida que profesan o finalmente del reprobado deseo de disfrutar mayores comodid $\mathrm{z}$ des y lograr premios para saciar su ambición...».

Se llegó a plantear la duda, en el Consejo, de si sería preciso abandonar el envío de religiosos europeos y dejar despoblados los conventos y colegios de misiones, desapareciendo las conversiones; o por el contrario someterse a pesar de estos inconvenientes que,

(1...aunque graves, eran infinitamente menores que los que resultarían de dejar tantas almas en las tinieblas del paganismo o en la privación de los consuelos de nuestra Santa Religión».

Hallaba, el Consejo, que aunque fuera cierto que muchos misioneros se corrompían y escandalizaban con su conducta, había gran exageración en esto, por un lado, y de lo cual tenían buenas pruebas de ello; y por otro, que producían

«... utilidades muy apreciables a la Religión y al Estado inspirando máximas de buena doctrina y de fidelidad al Soberano 
aun cuando las costumbres no sean tan puras como se pudieran desear... ».

La conclusión final fue de que era preferible tolerar el inconveniente de que algunos salieran «de mala vida $y$ costumbres» por el peligro de peores males. ${ }^{14}$

Malas consecuencias se podían derivar, indudablemente, de una rigurosa selección en una tierra donde había un corto número de clérigos. Aunque la isla de Cuba, en el siglo XIX, no estaba considerada como tierra de misión, en el sentido amplio de la palabra, como de expansión religiosa, de conversión de parganos al cristianismo, sí que necesitaba de abundantes «operarios» que proporcionaran el alimento espiritual a su cada día más numerosa población. Entre las tareas que más demandaban del clero los cubanos estaba, sin lugar a dudas, la de la enseñanza, labor que no siempre podían realizar por la escasez de personal.

Excelente enclave geográfico, zona de paso hacia otros puntos del Nuevo Mundo, en La Habana hacían escala un elevado número de religiosos en su largo viaje desde la metrópoli al continente americano o a la inversa. En 1819, dos religiosos franciscanos que desde la península iban destinados a enseñar las primeras letras en Guatemala, Ambrosio Giménez y Fernando Martínez, fueron retenidos por el gobernador, en la capital de la isla antillana, para que se ocuparan igualmente de la docencia tanto en aquella ciudad como en la villa de Guanabacoa, cuyo Ayuntamiento lo había solicitado anteriormente. ${ }^{15}$

Que los religiosos pudieron y debieron hacer más en el campo de la instrucción pública en Cuba está fuera de toda duda, pero no es menos cierto que fue muy grande su aportación a la cultura. $\mathrm{Si}$, como hemos visto, la conducta de muchos era merecedora al

14 A.G.I., Ultramar, \&. Consejo de Indias, 7 de junio de 1804.

15 A.G.I., Santo Domingo 1.155-B. El gobernador, Cienfuegos, a Esteban Lozano (Gracia y Justicia). La Habana, 3 de junio de 1819.

A.G.I., Santo Domingo, 1.291. Cienfuegos a Esteban Lozano. Le comunica que dos religiosos destinados a Guatemala los ha empleado en escuelas de primeras letras en aquella ciudad. En espera de real aprobación... La Habana, 3 de junio de 1819. 
menos de amonestación, también abundaron aquellos cuyos méritos estaban oscurecidos, a la sombra de su moderación y sus virtudes. Para premiar a estos últimos una real orden, de 3 de octubre de 1816, mandaba a los arzobispos y obispos de aquellos dominios que remitieran anualmente, por la vía reservada, listas de todos los eclesiásticos que se distinguieran por sus luces, por su ministerio, por su caridad. Por otro real decreto, fechado en Madrid el 13 de junio de 1819, el Ministerio de Gracia y Justicia, volvía a mandar a todas las personas constituidas en dignidad: arzobispos, obispos, rectores y cancelarios de las universidades, remitieran a la mayor brevedad posible listas, tanto de seculares como de regulares, que por su virtud y mérito debicran ser colocados en las prebendas y dignidades eclesiásticas.

«...dando preferencia a los párrocos que más hubiesen sobresalido en el cumplimiento de sus obligaciones, instruyendo, amparando y auxiliando a sus feligreses, interesándose en la educación de los niños de sus respectivas parroquias a los catedráticos de universidades y seminarios que mejor hubiesen llenado sus destinos....). ${ }^{16}$

Después de varios siglos en los que la labor sacerdotal había tenido un prestigio que rara vez fuera sometido a tela de juicio, en la centuria decimonónica los religiosos estuvieron expuestos a los fuertes vientos de la política imperante: con los gobiernos absolutistas de Fernando VII gozaron de protección; pero, en las épocas constitucionales, de gobiernos liberales y más si eran progresistas, fueron duramente criticados, reducidos, perseguidos y algunas órdenes incluso eliminadas. De las Cortes de Cádiz, por ejemplo, se quejaba Juan Bernardo O'Gavan, canónigo doctoral y provisor vicario de la catedral de La Habana y diputado por aquella provincia, de que

16 A.G.I., Santo Domingo, 2.213.

Tomo XLVIII 
«...en el Congreso por sostener la justicia cuando se hacía una guerra cruel al estado eclesiástico, sufrió una violenta persecución... La feliz llegada a V.M. puso término a los males que afligían a sus vasallos...). ${ }^{17}$

Efectivamente el retorno del monarca daba seguridad al estamento eclesiástico y garantizaba su participación en la enseñanza. Una real cédula, de 20 de octubre de 1817, ordenaba el establecimiento de escuelas en todos los claustros de regulares, de ambos sexos, para la docencia a niños y niñas pobres. Por razones económicas y políticas, Fernando VII, prefirió confiar la educación y el aprendizaje de las primeras letras a las órdenes religiosas.

Una Comisión nombrada por el capitán general de la isla y el obispo de La Habana se encargó de establecer los diálogos necesarios, con los prelados de los conventos de regulares y su. periores de los monasterios, con el fin de dar cumplimiento a lo mandado en octubre de 1817. En la capital habanera, en enero de 1819, se abrieron colegios para niños en los conventos de: Santo Domingo, San Francisco, San Agustín y La Merced; para niñas, en los monasterios de Santa Clara, Santa Catalina y Santa Teresa. Habría también, según comunicaba la Sociedad Patriótica de dicha ciudad, «escuelas caritativas» en todos los pueblos de ese obispado donde existiesen conventos de regulares. ${ }^{18}$

La colaboración de algunos miembros del clero indígena a favor de la independencia de las colonias -Morelos e Hidalgo en México, por ejemplo-, debió de ser la causa por la que en la Corte se mirara con recelo el hecho de que participaran en asuntos políticos sacerdotes de ultramar. Ya hemos visto cómo Bernardo O'Gavan se quejaba de la persecución a la que decía ser sometido por el Congreso de las Cortes de Cádiz.

17 A.G.I., Ultramar, 154. Juan Bernardo O'Gavan a S. M. Madrid, 20 de diciembre de 1814. Pedía que por su fidelidad y buen proceder se le concedieran los honores de ministro de la Audiencia de México o de Cuba. El 21 de enero de 1815 se le concedieron los de la Audiencia de Cuba (Puerto Príncipe).

18 A.G.I., Santo Domingo, 1.342. Memorias de la Real Sociedad Económica de La Habana, núm. 24. 31 de diciembre de 1818. Educación pública en las casa religiosas. 
La isla cubana, enclave intermedio entre Europa y las colonias hispanas, era terreno bien abonado donde podían fructificar las semillas del separatismo. Obligación de España era velar por su integridad territorial, por lo que no podía permanecer en silencio ante el intento, por parte de algunos religiosos, de sembrar las ideas de la independencia. En 1816, el gobernador de $\mathrm{La} \mathrm{Ha-}$ bana comunicaba a la Corte lo peligrosa que era la permanencia en aquella isla de fray Francisco de Paula Chacín, de la orden de la Merced, por sus antecedentes: natural de Caracas; había predicado dos sermones, uno en dicha ciudad y otro en el pueblo de La Guayra, con motivo de la instalación de la Junta Revolucionaria «profiriendo expresiones sediciosas para atraer a incautos, especialmente a la gente de color... para que odiasen a los europeos»; trasladado a Santo Domingo, el gobernador de esta isla, lo consideró emisario de los insurgentes por lo que lo envió al capitán general de Cuba quien, a su vez, lo remitió a Cádiz, donde fue juzgado el 18 de marzo de 1811. El gobierno de la Regencia ordenó fuese trasladado al convento de su orden en Mallorca, sin que pudiese volver a ningún territorio de América. Ocultando estos antecedentes, solicitó al Consejo, desde Barcelona, el 24 de diciembre de 1815 , licencia para poder embarcarse, acompañando el permiso del general de su orden, cuya gracia se le concedió e! 12 de enero de 1816. El gobernador de La Habana, viendo sus antecedentes sediciosos, mandó al prelado de su convento que observase su conducta hasta que el monarca resolviera, añadiendo que

"....semejantes sujetos no pueden estar en un país tan quieto como aquél sin correr riesgo la tranquilidad pública». ${ }^{19}$

Una ley, sancionada el 25 de octubre de 1820 , alteró durante el Trienio Liberal el sistema establecido; por ella, se suprimían

19 A.G.I., Ultramar, 3. Consejo de Indias, 15 de marzo de 1817. De acuerdo con el dictarnen del fiscal y el del Consejo, la Corona resolvió remitirlo «con el debido decoro» al convento de Mallorca para que cumpliera la sentencia que le estaba impuesta.

Tomo XLVIII 
los monasterios de las órdenes monacales hospitalarias de San Juan de Dios y Betlemitas, al tiempo que se ordenaba el arreglo de los conventos de los regulares. Los hospitales y las escuelas de primeras letras se encomendaron a los ayuntamientos de las localidades respectivas, los cuales tenían que proponer los arbitrios que consideraban más idóneos para su subsistencia, dando cuenta a la Corte, previo informe de la Diputación Provincial y del gobernador capitán general. ${ }^{20}$

Las quejas desde algunos sectores no se hicieron esperar. En Santiago de Cuba, su síndico procurador general, Tomás Creagh, exponía a la Corona los perjuicios públicos que podían dimanar de la supresión del hospital de los betlemitas, establecido en aquella ciudad; el desconsuelo del pueblo por

"...haberse desplomado... el único asilo de la humanidad doliente que existía... con escuelas de primeras letras, debido a la caridad, industria y desvelo de cuatro laboriosos operarios...).

Con respecto a los arbitrios oportunos que debía proponer el Ayuntamiento para restablecer el hospital y la enseñanza, expresaba, dicho síndico, «no alcanzar cuáles sean capaces de reemplazarlo» por cuyo motivo suplicaba recobrar a la mayor brevedad posible el consuelo de verlo restablecido, porque mucho lo necesitaba. ${ }^{21}$

Con las casas y bienes de los conventos suprimidos, se debía formar, según la mencionada ley, un crédito público cuyo objeto sería la extinción de la deuda nacional, por medio de las ventas

20 A.G.I., Ultramar, 106. El gobernador, capitán general de Cuba, Cagigal, a Antonio Porcel. Le expresa haber recibido la onden que con fecha 9 de noviembre de 1820 se le comunicó y el ejemplar de la ley de 25 de octubre de 1820. La Habana, 6 de febrero de 1821.

A.G.I., Santo Domingo, 1.293. Expediente formado en virtud de la ley y real orden sobre supresión de monacales y arreglo de regulares. Conventos de La Habana a los que repercute: San Agustín. San Juan de Dios y Nuestra Señora de Belén. Amplio documento de 3̌́0 folios.

21 A. G. I., Santo Domingo, 1.338. Tomás Creagh, síndico procurador general de Santiago de Cuba a S. M. Santiago de Cuba, 14 de marzo de 1821. 
que en pública subasta se hicieren, con arreglo a los decretos de las Cortes.

Con la intervención de los Cien Mil Hijos de San Luis y la consiguiente vuelta al poder absoluto de Fernando VII, se deshacía lo implantado en los tres años anteriores, volviendo el monarca a depositar su confianza en el clero en cuanto a la instrucción pública se refiere. Por ello, el 25 de marzo de 1824, se ordenaba a las autoridades que se excitara de nuevo a los religiosos para que dirigiesen y costeasen escuelas gratuitas.

Fruto de la política belicista del bando liberal fue la segunda supresión de las órdenes religiosas, en 1836-1837, con objeto de cubrir con sus bienes, entre otros fines, parte del déficit nacional. Con respecto a Cuba, su capitán general - Miguel Tacón-, proponía al Supremo Gobierno, a través del Ministerio de Hacienda, que se adoptasen las normas, consideradas más útiles, para la continuación de los establecimientos piadosos o de instrucción pública que estuvieran a cargo de las comunidades religiosas. Debían conservarse, en su opinión: a todo trance, el convento hospital de caridad de San Juan de Dios; también eran convenientes los conventos de franciscanos y el de misioneros capuchinos; recomendaba fervientemente a las monjas ursulinas, porque además de estar dedicadas a la enseñanza — decía—, eran dignas de elogio por sus virtudes y pobreza. Con respecto a la instrucción pública de los niños, sólo se dedicaban, por estas fechas, a la primera enseñanza los betlemitas y a la universitaria los dominicos; pero el concepto que sobre la labor de estos religiosos tenía el gobernante no sería muy bueno cuando comunicaba a dicho Ministerio:

"Sobran aquí colegios de instrucción primaria y la Universidad pudiera tomar otra forma más provechosa y ser susceptible de mejoras. Por cuya razón no considero ni a Belén ni a Santo Domingo en el caso de las religiosas ursulinas, utilísimas por su institutom. ${ }^{22}$

22 A.G.I., Santo Domingo, 1.306. Miguel Tacón, gobernador de La Habana, al" secretario del despacho de Hacienda. La Habana, 7 de febrero de 1838. 
Una ley sancionada en 30 de enero de 1838 disponía que la isla de Cuba debía contribuir a los gastos extraordinarios de la guerra (Carlista) con un subsidio de dos millones y medio de pesos y otros dos por cuenta de la enajenación de los bienes de los retgulares. Una Junta integrada por dos miembros de cada uno de los organismos principales de la isla sería la encargada de recaudar estos impuestos. ${ }^{23}$

El artículo $70^{\circ}$ del decreto de 30 de enero prevenía que no se procediera a la enajenación de los bienes de los conventos que en todo o en parte estuvieran dedicados a la beneficencia o a la instrucción pública, a menos que fuera imposible obtener de los otros los dos millones decretados; por esta razón, la primera labor de la Comisión de liquidación de los bienes de los regulares debía ser examinar la forma en que podrían separarse los que habrían de servir a la expresada enajenación hasta completar con sus bienes dichos dos millones. ${ }^{24}$

Posteriormente, el gobernante Espeleta, en nombre de la Comisión, informaba a la Corte que la enajenación de los bienes de los conventos, aunque se hiciese en los términos más favorables, no daría al Gobierno la cantidad señalada; y que produciría a aquellas Cajas Reales un gravamen anual, con disminución de los situados que se remitían a la península, si hubieran de cum-

23 A.G.I. Santo Domingo, 1.306. El gobernador, capitán general, Ezpeleta al secretario del Despacho de Hacienda. Contesta a la real orden que disponía que convocara una Junta compuesta por 12 vocales para ocuparse de los medios de realizar el subsidio extraordinario de guerra y la enajenación de los bienes de los regulares. Miembros de la Junta que se designaron:

- Por el Ayuntamiento: el conde de O'Reilly y Nicolás de Cárdenas.

- Por la Junta de Fomento: el conde Fernandina y José Pizarro.

- Pos la Junta Superior de la Real Hacienda: José María Zamora y Ramón Padilla.

- Por la Real Sociedad Económica: Juan Montalvo y Martín Pedroso.

- Por los hacendados: el conde de la Reunión y Narciso García de Mora.

- Por los del comercio: Joaquín Gómez y Juan Ignacio Echarte. El 20 de junio de 1838, el rey nombraba vicepresidente de la Junta de Subsidio de Guerra al intendente de La Habana. Con fechas 2 y 21 de julio de 1838 , el gobernador Ezpeleta informaba al secretario del Despacho de Hacienda de los trabajos de dicha Comisión.

24 Ibídem. Informe de la Comisión de liquidación de bienes de los regulares al gobernador Ezpeleta. La Habana, 3 de agosto de 1838. 
plir con las obligaciones y cargas de los establecimientos de beneficencia e instrucción pública, así como la subsistencia de los religiosos que también tenía que ser atendida. La enajenación no sería realizable —en opinión de la Comisión-, sino en una mínima parte y que distaba mucho «de llenar los deseos del Gobierno». Proponían proceder a la venta de los bienes de los betlemitas exclusivamente, por estimarse en algo más de dos millones de pesos, cantidad aproximada a la designada por la ley, si bien insistían que bajarían los precios cuando se tasaren y mucho más en la subasta pública. ${ }^{25}$

Mala época corría para que las autoridades de Madrid frenaran su proyecto de enajenación. El apoyo decidido de la Iglesia a la causa carlista generará una creciente oleada anticlerical, fomentada o al menos permitida por los progresistas en el Gobierno. La desamortización siguió su cauce para poder cubrir, entre otros beneficios, «las urgentes necesidades» de la guerra, aunque de ella no se obtuvo en la isla, como ocurriera en la península, el fruto que se esperaba. ${ }^{26}$

Las tensiones Iglesia-Estado llegaron hasta tal extremo que las relaciones entre España y el Vaticano se rompieron. ${ }^{27} \mathrm{La}$ enseñanza en la isla de Cuba, con la supresión de las órdenes religiosas, sufrió algunas consecuencias al no contar los ayuntamientos que en teoría se debían de hacer cargo de la misma, con los medios económicos y estructurales necesarios que el tema requería.

Veamos a continuación los efectivos con que contaban las órdenes religiosas, en aquella isla antillana, en 1837:

25 Ibídem. 8 de octubre de 1838.

26 A.G.I., Santo Domingo, 1.307. Una real cédula de 26 de diciembre de 1838 encargaba al gobernador de La Habana que contribuyera a promover la venta de las fincas enajenadas de la Real Hacienda y las del clero regular. Ezpeleta, el ¿0 de febrero de 1839, contestaba al ministro de Hacienda que cooperaría cuanto pudiera.

27 A.G.I., Santo Domingo, 1.307. Ramón, arzobispo administrador de La Habana al secretario del Despacho de Gracia y Justicia. Dice haber recibido la orden circular de 19 de abril de 1841 por la que lla Regencia provisional del reino previene no se use ni se permita usar de las bulas, breves, ni demás despachos que vengan de la Curia Romana sin que antes hayan obtenido el correspondiente pase del Gobierno. La Habana, 28 de junio de 1841. 


\section{CONVENTOS DE RELIGIOSOS EXISTENTES}

Ciudad

Francis- Domi- Betle- Mer- Capuchi- Agusti- Juacanos nicos mitas ced nos nos ninos

$\begin{array}{llllllll}\text { La Habana } & \text { X } & \text { X } & \text { X } & \text { X } & \text { X } & \text { X } & \text { X }\end{array}$

Santiago de Cuba X X

Puerto Príncipe $\mathrm{X}$

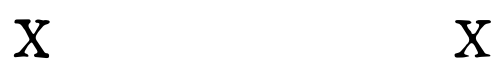

Bayamo $\quad \mathrm{X} \quad \mathrm{X}$

S. Espíritus $\mathrm{X} \quad \mathrm{X}$

Guanabacoa $\quad X \quad X$

Trinidad $\mathrm{X}$

Santa Clara $\quad \mathrm{X}$

MONASTERIOS DE MONJAS EXISTENTES

Ciudad

La Habana

Puerto Príncipe

\author{
Ursulinas
}

$\mathrm{X}$

$\mathrm{X}$
Santa Clara Catalinas

$\mathrm{X}$

$\mathrm{X}$

$\mathrm{X}$

NUMERO DE REGULARES EXISTENTES EN LA ISLA

Orden

Franciscanos

Dominicos

Mercedarios

Betlemitas

Juaninos

Agustinos

Capuchinos

Total

496
Conventos

Sacerdotes

Coristas y legos
9 (2 en La Habana)

4

2

2

2

1

1

21

150

86 
NUMERO LE MONJAS EXISTENTES EN LA HABANA

Monasterio

Santa Clara (Franciscanas)

Catalinas (Dominicas)

Santa Teresa (Carm. descalzas)

Ursulinas
Año da fundación

1644

1658

1702

1804
Profesas

31

24

18

29

Noricias

Total

102

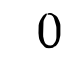

4

4

NUMERO DE MONJAS EXISTENTES EN PUERTO PRINCIPE

Monasterio

Ursulinas
Año de fundación

1817
Projesas

16
Novicias

$0^{28}$

La llegada al poder de los liberales moderados, en la década de los cuarenta, hizo posible la firma del Concordato con la Santa Sede, en 1851, en el que se reconocía al Gobierno español el derecho de Patronato y se daban como hechos consumados las ventas de los bienes de la Iglesia. Se permitía, a cambio, al estamento eclesiástico, el derecho a adquirir nuevos bienes, la dotación del culto y clero, la participación de la Iglesia en todos los grados de la enseñanza y otros beneficios.

El fruto del Concordato, en Cuba, se dejó sentir a partir de la real cédula de 26 de noviembre de 1852 por la que se establecían en dicha isla las siguientes órdenes religiosas: San Vicente de Paúl, padres escolapios, Compañía de Jesús y franciscanos. En el preámbulo del documento, la Corona, exponía las causas de su implantación:

«...carecer de pastores muchas parroquias de la diócesis de

Santiago de Cuba cuyo M. Rvdo. prelado ha reclamado de mi

28 A.G.I., Santo Domingo, 1.360. Datos obtenidos del resumen de los bienes de los regulares en la isla de Cuba, según informe de la Superintendencia de aquella Real Hacienda. La Habana, 12 de septiembre de 1837. 
Gobierno los sacerdotes necesarios para remediar esta dolorosa orfandad de sus iglesias; convencida además de que la educación religiosa de las clases pobres... no está atendida en la isla como conviene... confiándose la de las clases más acomodadas a manos mercenarias que frecuentemente la convierten en objeto de especulación mercantil y aun a veces en instrumento de reprobadas y apasionadas miras políticas... y conviniendo... que la numerosa población de color, que reside en las fincas de campo, pueda recibir en ellos la enseñanza religiosa...). ${ }^{29}$

El ejercicio de la docencia, una vez más, justificaba la presencia del clero en aquella isla antillana. Del resto del contenido de dicha cédula, ya trataremos cuando hagamos un estudio pormenorizado de las órdenes religiosas afectadas por el mismo.

La participación del clero en la formación de la población cubana está fuera de toda duda aunque, en algunos momentos o para determinadas personas, fuera negativa. Pero veamos, por último, cuál era la opinión de la Corte a este respecto. Si bien es cierto que el Gobierno del Estado, cuya primera cabeza dirigente -la Corona-, ostentaba el título de Católica Majestad, tradicionalmente venía dejando el control moral de la sociedad en manos de la Iglesia, cuando los resultados no sean los apetecidos, no tendrá inconveniente en someter a un severo análisis la actuación de los religiosos. Veamos un ejemplo que nos aclare esta afirmación.

El general Concha, el 15 de marzo de 1851 , remitía a la Corte su célebre «Memorial» en el que exponía que la instrucción primaria estaba en estado lamentable. El 24 de mayo del mismo año, un oficial del negociado de la Gobernación de Ultramar «entendía» que la postración de la enseñanza en Cuba, descrita por el gobernador, la falta de asistencia de los alumnos, el reducido número de escuelas existentes, etc., no dimanaban tan sólo de la carencia de fondos sino que provenía, en primer lugar, del estado de la moralidad de aquella provincia ultramarina, por lo que se debía

29 A.H.N., Ultramar, 35, núm. 62.

Tomo XLVIII 
"...evaluar la razonable influencia de los ministros de la Religión Católica en la vida doméstica y pública... y su intervención en la vida literaria y en la primera enseñanza...».

Igualmente añadía que

... " "...convendría recoger datos sobre las costumbres del clero... que arrojen algunas luz... ya que no ha sido tocado eqte delicadísimo punto en el informe del gobernador sobre el estado de la opinión pública en la isla... Posiblemente el Plan vigente desde 1842 vaya descubriendo imperfecciones que reclamarán urgente remedio".

La duda sobre la influencia positiva del clero en la sociedad cubana debía de ser compartida por muchos en la Corte cuanclo la real resolución fue, como proponía el oficial en su nota, qud se pidiera a Gracia y Justicia un informe razonado de los cincuenta años del siglo de cuantos datos hubiera sobre costumbres del clero de Cuba y de su cooperación en las escuelas de primeras letras: igualmente, se les pedía su parecer, acerca de la participación que en un futuro pudiera darse al estado eclesiástico en instrucción primaria.

Gracia y Justicia, en contestación a Ultramar, de 13 de mayo de 1852, remitía el dictamen del Consejo Real en el que decía que en su archivo no se encontraba expediente que contuviese reglamento ni disposición general sobre instrucción primaria en Cuba, hallándose tan sólo algunos documentos sobre establecimientos de escuelas en varios pueblos de la misma; que tampoco se encontraba nada sobre costumbres del clero de aquel país, porque de instruirse algún expediente hubiese sido por la vía reservada; por último, su Consejo, se abstenía de sentar bases sobre las que cimentar la enseñanza de las primeras letras en dicha isla por pertenecer al de Ultramar determinar la participación que en la misma debía tener el clero.

La resolución final, ante la falta de datos en la Corte, fue solicitar al capitán general de la isla, en 15 de julio de 1852, que 
informase nuevamente sobre el punto principal de arreglo de la instrucción «con la debida separación» bajo los tres aspectos: moral o religioso, de interés social y económico de actualidad, adjuntando los pareceres de la inspección de estudios y de otras autoridades de su gobernación. ${ }^{30}$

En Madrid se juzgaba que una posible causa del «lamentable» estado de la instrucción de la isla podría ser las malas costumbres del clero cubano. Los religiosos, por su parte, como efecto de rebote, culpaban a las autoridades de los defectos morales de aquella población. Bajo esta perspectiva se comprenden fácilmente las palabras de Ismael Teste, eclesiástico cubano de nuestro tiempo, cuando dice:

"Para muchos cubanos decir Religión Católica y Gobierno Español era la misma cosa, y las consecuencias de esta confusión fueron fatales en muchísimas cosas para la verdadera formación cristiana del cubano ya que la conducta de los gobernantes en muchos casos no correspondía a sus principios religiosos). ${ }^{31}$

Como resumen final, antes de referirnos al estudio individual de las órdenes religiosas que participaron en las tareas educativas en Cuba durante el siglo XIX, queremos destacar:

1.) Que tanto las autoridades de Madrid como las de la isla y el pueblo cubano delegaron en el clero, cuando su existencia lo permitió, los asuntos de enseñanza.

2..) Que se aprecian tres etapas claramente diferenciadas: a) 1812-1840, en la que conviven con mayor o menor armonía con el pueblo cubano las órdenes que a lo largo de las centurias o en el mismo siglo XIX se han ido fundando (si exceptuamos el sobresalto dado durante el Trienio Constitucional); b) 1840-1852, años de ruptura entre Iglesia y Estado español, durante los cualés se hallan suprimidos los regulares; c) $1852-1868$, período de re-

30 A.H.N., Ultramar, 24, núm. 1.

31 Teste, J.: Historia eclesiástica..., tomo V, pág. 196.

Tomo XLVIII 
novación de algunas órdenes y de instalación de otras nuevas como escolapios, San Vicente de Paúl, etc.

3..$\left.^{\circ}\right)$ Pocos se dedicaron a la enseñanza de las primeras letras de una forma habitual. Dominicos, franciscanos y jesuitas aportaron una mayor labor a lo que hoy consideramos como segunda: enseñanza.

4..$^{\circ}$ Todos los religiosos, sin excepción, decían dedicarse a la instrucción pública aunque ésta sólo consistiera en la doctrina cristiana, catecismo, principios de orden, formación de novicias, etc.

B) Ordenes religiosas

\section{Betlemitas}

La orden religiosa hospitalaria de los betlemitas, vulgamente llamados belemitas, fue fundada por el venerable tinerfeño Pedro de San José de Bethencourt, en Guatemala en 1655. Pronto pasaron a esta isla antillana en la que, a comienzos de la centuria decimonónica, contaban con dos conventos: uno en La Habana y el segundo en Santiago de Cuba.

Tratamos, en primer lugar, de esta orden, porque sin lugar a dudas ellos fueron los que más se dedicaron a la enseñanza de las primeras letras, y a veces fueron los únicos.

\section{1.-Los betlemitas en La Habana}

La Casa de Convalecencia de Belén, en La Habana, fue la segunda de las fundadas por esta orden (la primera se estableció en Guatemala), para socorrer a todos aquellos que salían del hospital sin terminar su curación. A las gestiones del obispo Compostela, en 1695, se debe su instalación en la capital habanera, siendo fray Francisco del Rosario y fray Julián de San Bartolomé los pri- 
meros religiosos betlemitas que llegaron a la isla, en 1704, y que fueron hospedados por dicho prelado en su casa de la Huerta de San Diego.

El benefactor principal de este convento y hospital de Belén fue Juan Francisco Carvallo, alférez de milicias y rico mercader, quien compró todas las casas de la manzana para que se pudiera edificar en ella la iglesia y la casa de los religioses. Muerto Carvallo, en 1718, el obispo - Jerónimo Valdés-, con iguió de la Corona (a pesar de la oposición del capitán general Guaso Calderón), que todos sus cuantiosos bienes fuesen destinados a continuar la obra de los betlemitas. ${ }^{32}$

La actividad de estos religiosos estaba al servicio de la comunidad: de la iglesia y oficios divinos pasaban al hospital y de aquí a las escuelas u otras oficinas y empleos donde de nuevo se ejercitaban en la caridad pública.

Tanto en el hospital como en la escuela de los betlemitas de La Habana se admitían «a toda clase de individuos blancos, pardos y morenos, de cualquier condición y estado, sin exclusión de miserables» pero estaban «con la debida separación». Refiriéndose a la educación de los niños «de color», el obispo de La Habana', comunicaba a la Corte que no eran ciertos los datos dados por José de la Luz Aguiar de que no se admitían los negros en las escuelas de los blancos puesto que entraban en varias y principalmente en las de los betlemitas. ${ }^{33}$ Según las cifras de la única estadística que disponemos en la que figuran los alumnos separados por «color », la de 1783 , el 72'83 \% eran blancos y el $27 ' 17 \%$ restante de pardos y morenos. No hay razones que nos lleven a pensar que variase mucho esta proporción en el siglo XIX por lo que podemos deducir que de cada cuatro alumnos, tres eranl blancos y uno «de color».

Una real cédula de 17 de julio de $176 \not$ mandaba que los varones expósitos se pusieran en el hospital de los betlemitas cuan-

32 Ibídem, tomo $\mathrm{V}$, págs. 238-241, y tomo I, pág. 120. Ascendian dichos bienes, según reales cédulas de la época, a 200.000 pesos.

33 A.G.I., Santo Domingo, 2.236. Juan José, obispo, a Miguel de Lardizábal y Uribe. La Habana, 5 de mayo de 1815. 
do cumplieran los cinco años para que aprendieran las primeras letras; pero esta orden, no se llevó a cabo.

Los locales escolares del convento consistían:

"...en un salón muy largo, que se compone de cuatro piezas, quitadas las divisiones donde había copioso número de muchachos escribiendo... Fuera del salón había dos claustros todos llenos de escolares, con tres maestros religiosos belemitas ( sic)...). ${ }^{34}$

En cuanto a los alumnos asistentes a estas escuelas es difícil precisar su número exacto puesto que, como manifestaba su viceprefecto en 1795, no llevaban «libros de asientos», pero sí poder mos afirmar dos cosas: primera, que al finalizar el siglo XVIII tenían casi tantos discípulos en sus aulas como juntos todos los de las demás de La Habana (incluso más, según la opinión de su viceprefecto); ${ }^{35}$ segunda, que a lo largo de la decimonona centuria, su número de alumnos, fue disminuyendo hasta la total desaparición de la orden en 1841.

Veamos los datos de que disponemos y que avalan los asertos anteriores:

En 1783 asistían al centro betlemita 552 niños distribuidos de la siguiente forma:

De escribir y contar

Blancos

Pardos y morenos

Totales
212

60

272
De leer

Total

402

150

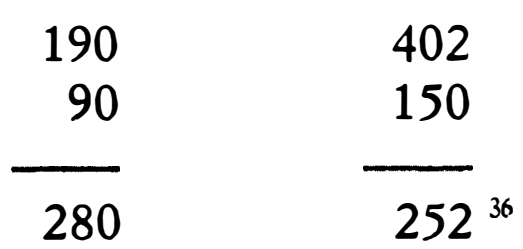

34 A.G.I., Ultramar, 117. Fray Andrés de Santa Bárbara, viceprefecto del convento y hospital de Belén al obispo de La Habana. La Habana, 9 de febrero de 1795. Solicita que el frovisor y vicario general, asistido del notario mayor de la Curia pasase a hacer un reconocimiento del establecimiento betlemítico. Por mandato del prelado, el presbítero abogado, provisor y vicario general, don Esteban José Conde, acompañado del notario mayor, visitaron el convento el 11 de febrero de 1795.

35 Ibídem.

36 Ibidem. 
En 1819 , en un estado de cuentas que presentaba el convento hospital de Belén en La Habana desde 1784, después de manifestar los que entraban al año en la convalecencia, lo que gastaban, dietas, número de muertos, etc., hacían una serie de advertencias, de las que destacamos la cuarta, en la que expresaban que el convento sostenía

«...una escuela de primeras letras, con la mayor brillantez, regentada por los mismos religiosos, a la que asisten diariamente como 400 niños...). ${ }^{37}$

La disminución de escolares en las aulas betlemitas en esas fechas - 1819- debió ser consecuencia de la real orden de 20 de octubre de 1817 por la que se establecían escuelas caritativas en otros conventos de la capital.

Reanudada su tarea después del período de supresión de la orden, durante el Trienio Constitucional (1820-1823), la matrícula volvió a sufrir otro descenso considerable. En 1825, el vicepresidente del convento exponía el siguiente estado de sus escuelas, en cuanto a número de alumnos:

Niños de leer

Niños de escribir

\section{Total}

257. ${ }^{38}$

En 1837, según el informe de la Capitanía General de la isla, elaborado con motivo de la orden de supresión de las comunidades regulares, entre las cargas de los betlemitas figura:

37 A.G.I., Ultramar, 117. Estado que maniflesta... el convento Hospital de Padres Bellemitas de La Habana, desde 1784 hasta 1819.

38 Ibídem. Fray Pedro de la Natividad, vice-presidente del Convento Hospital de Belén al obispo de la diócesis. La Habana, 30 de abril de 1825. Expe-1 diente formado a consecuencia de la comunicación que hace dicho vice-presidente al prelado de la venta de unas casas para pagar deudas. 
"Un escuela gratuita de prineras letras parat la cnseñanzal de más de 200 niños...). ${ }^{39}$

Además de la enseñanza de la lectura y escritura hubo algura época en que impartieron clases de aritmética y ortografía; así, en 1795, «había más de cuarenta» niños que se beneficiaban de estos aprendizajes. ${ }^{40}$ Igualmente nos consta que, en 1817 , la Sociedad Económica de La Habana estaba dando los pasos oportunos para poder establecer una escuela gratuita de matemáticas en el convento de Belén; pero, a raíz de la disposición de la Corte de que se pusieran escuelas en todos los claustros de regulares para la enseñanza de niños y niñas pobres, estimó oportuno, dicha Sociedad, esperar al cumplimiento de esta orden. Sobre la enseñanza de las matemáticas en el mismo, nunca más se volvió a hablar. ${ }^{41}$

Nada hemos encontrado que nos permita hablar de la meto. dología empleada por estos religiosos; tan sólo que practicaban los niños seis diferentes clases de letra. Nos sorprende que enseñasen por separado la lectura de la escritura; suponemos que el conocimiento de la primera debía preceder a la adquisición de destrezas que hicieran posible el dominio de la segunda.

Si observamos detenidamente la estadística de 1783 los blancos asistían en mayor número a las clases de escribir y contarl mientras en pardos y morenos ocurría lo contrario, esto nos muestra el mayor nivel cultural de los primeros.

A todos los alumnos, sin excepción, se les suministraba gratuitamente la tinta por lo que era denominada «de gracia»; a los considerados como muy pobres, les socorría el convento dándoles todo lo necesario para su enseñanza: plumas, papel, libros, etc.

39 A.G.I., Santo Domingo, 1.306. Resumen específico de los bienes que poseen los regulares de ambos sexos en la isla de Cuba. La Habana, 12 de septiembre de 1837.

40 A.G.I., Ultramar, 117. Informe del provisor y vicario general, don Esteban José Conde al obispo, sobre el reconocimiento practicado al convento y hospital de Belén. La Habana, 11 de febrero 1795.

41 A.G.I., Santo Domingo, 1.342. Memorias de la Real Sociedad Éconómica en 1818. Pág. 19. 
El convento hospital de Belén tenía una situación privilegiada y disponía de una gran capacidad por lo que los autoridades civiles, en las épocas de supresión de la orden, siempre contaron con este edificio para otros usos. En septiembre de 1820 la Diputación Provincial de La Habana solicitaba al gobierno constitucional de Madrid, que se alojara en él el batallón de Cataluña:

(....sin perjuicio de las salas destinadas a la convalecencia de enfermos y a la enseñanza de primeras letras...... ${ }^{42}$

El capitán general Nicolás Mahy, en abril de 1821,dirigía al Gobierno Supremo la propuesta de la Diputación Provincial habanera de que se destinara el convento de los extinguidos betlemitas para establecer en él la universidad provincial. La Comisión de Educación nombrada a este efecto, por dicha Diputación, exponía en su informe que debiendo establecerse en La Habana una universidad, según el proyecto. del Plan General de Enseñanza Secundaria presentado a las Cortes, se necesitaba un edificio bastante capaz y sin dependencia de ninguna corporación extraña

«...como la tiene - añadían - actualmente con tantos defectos en el convento de Santo Domingon.

Fundaba la Comisión su dictamen en el artículo 132 de dicho proyecto que facultaba al Gobierno para reservar con este fin cualquier edificio de las extinguidas comunidades monacales. ${ }^{43}$

42 A.G.I., Santo Domingo, 1.291. Juan M. Echeverri a Antonio Porcel. La Habana, 9 de septiembre de 1820 . Además de las razones de capacidad y saludable situación alegaba, dicho señor Echeverri, que existian en él pocos religiosos y esperando algunos secularizarse.

43 A.G.I., Ultramar, 107. Nicolás Mahy a Ramón Gil de la Cuadra (Ultramar). La Habana, 14 de abril de 1821. Una real orden de 6 de diciembre de 1820 . había dispuesto que solamente subsistiese destinado para alojamiento del batallón 1.0 de Cataluña hasta que, minorada otra vez la guarnición volviese dicho cuerpo. a ocupar el castillo de la Cabaña, en el que se hallaba u otro que se le señalase. Para proceder a la resolución de lo solicitado por la Diputación Provincial, Su Majestad resolvió, en 28 de julio de 1821 que el secretario del Despacho de la Guerra informase sobre el particular. No hemos encontrado la contestación de dicho señor ministro. 
El real decreto de 1 de octubre de 1823 por el que se anulaba todo lo hecho «en el llamado sistema constitucional» hizo que volviera la orden betlemita a su actividad normal, en el expresado convento.

Hasta 1841 en que desapareció la orden, los betlemitas impartieron enseñanza primaria en su convento. Ya veíamos cómo, en 1838, el capitán general Miguel Tacón exponía a la Corte que eran los únicos religiosos que se dedicaban a esta tarea, pero también añadía que no los consideraba necesarios por sobrar colegios de instrucción primaria; sin embargo, sabemos, que para evitar los daños que supondría el cierre de estas escuelas, la Superintendencia de la Real Hacienda en La Habana, hasta 1849, las subvencionó con 9.497 pesos al año, y a partir de esa fecha con 6.000 pesos anuales, pagados a la Inspección de Estudios a razón de 500 mensuales. ${ }^{44}$

El amplio convento de Belén, desaparecida la orden, fue ocupado para diversas dependencias oficiales. En 1854 la Compañía de Jesús estableció en él su colegio.

\section{2.-Los betlemitas en Santiago de Cuba}

Por una real cédula de 29 de julio de 1756 se mandaba entregar a la religión betlemítica un hospital con su iglesia existente en la capital de la parte oriental de la isla. El estado del edificio era tan deporable que para poder permanecer de pie estaba apuntalado. Las rentas con que contaba eran tan menguadas -166 pesos- que no eran suficientes para el sostenimiento de los religiosos por lo que necesitaron ser auxiliados por sus compañeros del convento de Belén de La Habana.

Los desvelos de la comunidad betlemítica en Santiago de Cuba dieron tan buenos resultados, en el aspecto económico, que a comienzos del siglo XIX estaban en condiciones de solicitar la

44 A.H.N., Ultramar, 32, núm. 2. Sobre adopción de arbitrios para atender a la instrucción primaria y al señalamiento de una cantidad alzada para sostener las escuelas que fueron de los religiosos betlemitas. 1848-1856. 
construcción de un nuevo edificio, extramuros de la ciudad, obra que no llegó a producirse.

El convento-hospital de Belén en Santiago de Cuba, aunque viejo y destartalado, era muy amplio. Según exponía su padrepresidente al arzobispo, podía destinarse (cuando se trasladaran al que pensaban edificar) para hospital de mujeres, Casa de Recogidas de penitenciadas, Casa de Niños Expósitos y escuela de niñas, puesto que «para todo ofrecía capacidad». ${ }^{45}$

La sala que más nos importa del recinto es la que estaba destinada a aula de clase. Se trataba de un rectángulo de 23'5 varas de largo y 7 de ancho; es decir, 19'62 metros de largo por 5'84 de ancho. Total 114'59 metros cuadrados. A pesar de ser «cómoda» y «de una ventilación libre» se hacía necesaria otra sala más, port concurrir a ella 204 niños, con lo cual no contaban, o de mayor amplitud la existente, "para evitar el contagio y la opresión»: Esto sólo se podría solucionar, según el padre-presidente, con la nueva obra del convento. ${ }^{46}$

Del informe que de la visita a esta escuela se hace, en $1816,{ }^{47}$ hemos podido obtener abundantes datos. Sabemos, por ejemplo, que en el aula había, entre otro material: roperos, bancas con sus correspondientes tinteros así como los asientos respectivos (otros utensilios dicen expresarse en el inventario exhibido por el señor presidente pero no figuran en el documento). Al frente de la entrada había un «altarito» con la efigie de Nuestra Señora de Belén y en el lado opuesto la silla del maestro con su correspondiente mesa acondicionada.

En cuanto a la limpieza, el comisionado de la visita la califica

45 A.G.I., Ultramar, 34. Fray Antonio del Rosario a don Joaquín Oses. Hospital de Belén. 28 de marzo de 1813. Le vuelve a ofrecer el ediffcio del convento hospital que habitan, para cuando ediflquen el nuevo, extramuros de la ciudad, como ya le expusieron en 1803 .

46 A.G.I., Ultramar, 30. Visita de la escuela de primeras letras a cargo de los religiosos del convento de Nuestra Señora de Belén. Santiago de Cuba, 19 de abril de 1816. Participan en la visita: el Sr. comisionado, licenciado Mena; è padre betlemita presidente, fray Antonio del Rosario; el maestro clérigo, presbítero don Manuel Correoso; actúa de secretario, Antonio Aguirre.

47 Ibídem. 
de regular, si bien es cierto que justificaba su deficiencia alegando que era «quanta permite la antigua fábrica de este convento». Igual que ocurría en el convento de Belén de La Habana, en el de Santiago de Cuba eran admitidos tanto los niños blancos como los de color, pero separados unos de otros «por contribuir así a la decencia y la educación».

Los niños que asistían a la escuela de Belén no pagaban estipendio alguno; todos los gastos que ocasionaba su enseñanza salían de la masa general de bienes y fondos correspondientes al hospital. Con respecto al clérigo encargado de la clase - presbítero Correoso en 1816-, afirmaba llevar mấs de tres años sirviendo la escuela sin otra renta que los 15 pesos que tenía asignados como segundo capellán del hospital, si bien añadía «con la esperanza de su premio».

El Plan de Enseñanza en este centro educativo era el siguiente:

- Horario: de 7 a 11 de la mañana y de 2 a 6 de la tarde (8 horas).

- Lectura en distintas obras, todas ellas «espirituales y de saludables máximas cristianas, políticas y morales...».

- Oraciones: por el maestro Jerónimo de Ripalda.

- Doctrina Cristiana: la aprenden de memoria de la contenida en el catecismo de Ripalda.

- Escritura de planas que eran corregidas por el maestro.

- Tipos de pautas: «según la nueva arte de escribir inventada por el maestro Pedro Díaz Morantes; ilustrada con muestras originales y varios discursos... por D. Francisco Xavier Palomares... cuyo autor único ha sido el que se ha mandado guardar en todas las escuelas por el Reverendísimo Padre General de la Orden».

- Organización: divididos en decuriones.

- Exámenes: todas las semanas, de catecismo, ortografía, reglas de aritmética y muestras.

- Otras actividades en las que se les instruía: ayudar a misa. 
En cuanto a la disciplina, según informaba el presidente de la orden y el presbítero encargado de la escuela al señor comisionado, el trato que se les daba a los niños era «suave, prudente y moderado»; tenían para con ellos «toda la consideración que la edad recomienda» para luego añadir que no se descuidaban y cuando el caso lo requería eran fuertemente castigados

«....sin el menor exceso de suerte que no se hallan en esta escuela aquellos instrumentos ásperos y opuestos a nuestra sabia legislación, sino los bastantes al terror y la corrección”.

Se trataba, por tanto, de una disciplina muy severa, deducción a la que también nos lleva otra frase del informe en la que manifiestan no perder de vista el «sofocar y reprimir el orgullo de los niños para hacerlos humildes de corazỏn, según los preceptos del evangelio». El objetivo primero que se proponía era que los niños adquiriesen buenas costumbres y modales, siendo un elemento fundamental para ello el orden. Del aula no se les permitía salir, ni siquiera para hacer sus necesidades

(1...ni aun de dos en dos, sino uno en pos de otro regresado que sea el primero, a menos que la urgencia no dé espera, evitando de este modo la ociosidad, pérdida de tiempo y otras consecuencias). ${ }^{48}$

Las prácticas religiosas predominaban en el sistema educativo betlemítico. Además de las lecturas piadosas, oraciones, cátecismo y doctrina, aprendidos de forma memorística, inclinaban a los niños a recibir con frecuencia los Santos Sacramentos y a asistir diariamente al Santo Sacrificio de la Misa.

Cuando adquirían los conocimientos primarios en este centro, los alumnos que más destacaban eran encauzados para las clases de latinidad y otras superiores; aquellos niños que los betlemitas consideraban que por su corta capacidad u otros impedi-

48 Ibídem. 
mentos no eran aptos para estudios mayores, recomendaban a sus padres que, sin pérdida de tiempo, los aplicaran a las artes $y$ oficios.

También debemos de mencionar aquí la gestación de un proyecto aunque no llegara a realidad. El 24 de septiembre de 1819, el gobernador de Santiago de Cuba, Eusebio Escudero, remitía al ministro de Gracia y Justicia el expediente promovido por su secretario, José Emigdio Maldonado, en el que se solicitaba la fundación de un hospital de mujeres desamparadas. Proponían que pasaran a su ciudad dos fundadoras del beaterio de betlemitas de Guatemala para que ejercieran su hospitalidad y al mismo tiempo se emplearan en la educación de las niñas. ${ }^{49}$ Los sucesos políticos acontecidos en la península en 1820, que dieron lugar al cambio del gobierno absolutista por otro liberal, imposibilitaron el que se llevara a efecto lo solicitado; incluso, algo peor, que se anularan las clases dadas por los betlemitas a los niños. El Ayuntamiento de Santiago de Cuba, en 1821, lo que pedía a Su Majestad era que se restableciera la escuela de primeras letras que existía en el convento betlemita, por considerarla de mucha necesidad. ${ }^{50}$

Concluido el Trienio Constitucional, esta orden hospitalaria, vuelve a impartir la enseñanza. Pero nuevos problemas la acechan: la independencia de México hace que por unos años se encuentren

49 A.G.I., Santo Domingo, 1.291 y Ultramar, 35. Eusebio Escudero al ministro de Gracia y Justicia. Cuba, 24 de septiembre de 1819. Maniflesta que la ciudad tiene 32.938 almas y que estremece el desamparo de infelices mujeres enfermas que mueren en las chozas por falta de alimentos y demás socorros, Que en Guatemala se halla establecido un beaterio de betlemitas mujeres, que atendía la enseñanza de las primeras letras a las niñas y costura, al tiempo que la hospitalidad de su sexo; que estaban sometidas a los religiosos betlemitas que eran quienes las auxiliaban. Hacían constar que puesto que en su ciudad. Cuba, había un convento de esta Orden «que por la industria de su prelada actual se halla en estado de opulencia» y habiendo, por otra parte, «mucha necesidad de una casa de educación pública para las niñas», rogaban que Su Majestad se dignara ordenar al general de la Orden betlemítica, residente n México, para que vinieran dichas dos fundadoras, aunque quedara sujeto el hospital bajo las mismas constituciones del de Guatemala o bajo los estatutos y reglamentos del de San Francisco de Paula de La Habana, con las variaciones convenientes de hacer.

50 A.G.I., Santo Domingo, 1.339. Tomás Creagh, síndico procurador general del Ayuntamiento de Santiago de Cuba a Su Majestad. Cuba, 14 de marzo de 1821. 
incomunicados con sus prelados generales que residían en la capital de Nueva España; por otro lado, a pesar de que eran varios los individuos que habían emigrado de las provincias disidentes, preferían domiciliarse en el convento de La Habana y no en el de Santiago de Cuba, por lo que tenían el grave inconveniente de la falta de religiosos. El 18 de mayo de 1830, los dos prelados de betlemitas de la isla, manifestaban a la Corte estas circunstancias y solicitaban que mientras permanecieran incomunicados, se les autorizase que de mutuo acuerdo pudieran trasladar indistintamente de uno a otro convento sus individuos, bien por tiempo determinado o indefinido. Solicitud que les fue concedida. ${ }^{51}$

En la relación de bienes de los regulares, hecha en septiembre de 1837, con motivo de la orden de supresión de los mismos, consta que en el convento de Belén de Santiago de Cuba tan sólo había cuatro individuos, todos legos. Entre sus cargas figura el hospital de caridad que sostenían pero ya no se hacía mención alguna a la escuela de primeras letras que, tal vez habría desaparecido, por falta de personal que la pudiera atender. ${ }^{52}$

\section{FRANCISCANOS}

Los frailes franciscanos fueron los primeros que llegaron al Nuevo Mundo. Ya iban en el segundo viaje de Colón. Según comenta Teste, Diego Velázquez llevó cuatro de estos religiosos a la conquista de Cuba, los cuales se quedaron en aquella parte oriental de la isla. ${ }^{53}$

También fue la orden de San Francisco la primera en establecer un convento en aquel territorio antillano (en La Habana en 1576) y la que con mayor número de comunidades (ocho) y religiosos contaba, en el primer tercio del siglo XIX. Las locali-

51 A.G.I., Ultramar, 6. La instancia de los prelados, dirigida al Ministerio de Gracia y Justicia, fue enviada a consulta del Consejo de Indias, quien resolviö en 28 de julio de 1830 .

52 A.G.I., Santo Domingo, 1.306. Resumen específico de los bienes que poseen los regulares en la isla de Cuba. 1837.

53 Teste, I.: Historia eclesiástica.... tomo IV, pág. 31. 
dades que tenían conventos franciscanos eran: La Habana (dos), Santiago de Cuba, Bayamo, Puerto Príncipe, Sancti Espíritus, Santa Clara, Trinidad y Guanabacoa.

Después de los betlemitas es posible que los franciscanos fueran los religiosos que más aportaran a la enseñanza primaria de los niños cubanos. Varios testimonios apuntan hacia esta posibilidad. Jacobo de la Pezuela, en su Diccionario..., expresa que

"Los franciscanos desde que se reunieron en sus primeros conventos enseñaban las primeras letras a muchos niños de los pueblos, gratuitamente a los que pertenecían a familias indigentes, o por módico estipendio a los de las familias regularmente acomodadas). ${ }^{54}$

Veíamos, en la primera parte de este estudio, cómo la conducta relajada de algunos franciscanos ponía a la Corte en la duda de si sería preferible no enviar ninguno más. Una «madura reflexión» en el Consejo de Indias les llevaría a la conclusión de que de esas faltas, aunque graves, resultaban inconvenientes mucho menores que los que se derivarían de dejar a las almas sin el alimento espiritual; que si bien era cierto que muchos misioneros se corrompían y escandalizaban con su conducta, también era seguro que había exageración en ello; y que, a pesar de todo, producían «utilidades muy apreciables a la religión y al Estado». ${ }^{55}$

Trataremos, en primer lugar, de los franciscanos instalados en Guanabacoa. Ya comentábamos que en la real cédula de fundación del convento de San Antonio, de religiosos observantes de San Francisco de Guanabacoa, de 19 de diciembre de 1721, se acreditaba que el motivo que tuvieron los vecinos de esa villa para recibirlos en su población fue el que atendiesen a la educación. Desde esa fecha hasta 1790 se dedicaron a la enseñanza de las primeras letras y de la lengua latina. El «espíritu de división» y «la mano larga con que se concedieron las secularizaciones»

54 Pezuela, Jacobo de la: Diccionario Geográfico, estadístico e histórico de la isla de Cuba. Madrid, 1863-1866, 4 vols., tomo III, pág. 432.

55 A.G.I., Santo Domingo, 2.241 y Ultramar, 2. 
redujo al convento a su absoluto abandono y por falta de religiosos tuvo que cesar la docencia. Aunque la disminución de efectivos era evidente, el Ayuntamiento de Guanabacoa, a finales del siglo XVIII, reclamó al padre provincial de la orden que abriera una escuela, conforme a la obligación que contrajo; ante la negativa del prelado de San Francisco, de que sus subordinados se dedicaran a la enseñanza, por considerarla incompatible con el estado de recogimiento y abstracción que debían de tener, y alegar que prefería la recolección de operarios misioneros para las Floridas que los enseñantes, la Justicia y Ayuntamiento de la villa recurrieron al Consejo de Indias, demandando centros de enseñanza, tanto en el convento de los franciscanos como en el de los dominicos. ${ }^{56}$

La diferencia de criterio entre religiosos de Guanabacoa y Ayuntamiento fue la causa de que se plantearan en el Consejo si era de utilidad la enseñanza de las primeras letras, si era conveniente el estudio de filosofía y teología y de si convendría utilizar a los religiosos de los conventos en la enseñanza. De todo ello ya hemos tratado anteriormente.

De los franciscanos en Santa Clara sabemos que, a comienzos del siglo XIX, se ocupaban de la enseñanza. Manuel Quintana, miembro de dicha orden, en 1809 , manifestaba que había sido destinado como maestro de latinidad y de una escuela de primeras letras, situada en el Hospicio de dicha villa; que había permanecido en este destino cinco años, en cuyo cumplimiento había sido eficaz tanto en el ministerio sacerdotal como en el de la enseñanza. ${ }^{57}$

No tenemos motivos para suponer que no siguieran impartiendo docencia estos religiosos; al menos desde 1817 que por

56 A. G. I., Ultramar, 13. Oficio del Ayuntamiento de Guanabacoa al Provincial de los franciscanos. Guanabacoa, 10 de septiembre de 1797. Los vecinos recurrieron al Ayuntamiento exponiendo los perjuicios de la falta de educación pública, en 23 de enero de 1800 . El Consejo de Indias acordó mandar al capitán general de la isla que se formara nuevo expediente, oyendo a los provinciales de franciscanos y dominicos y a la Universidad. La caria de don Antonio Porcel al gobernador de La Habana fue de fecha 10 de agosto de 1804.

57 A.G.I., Santo Domingo, 2.231. Manuel de Quintana a Martín de Garay. Santa Clara, 8 de diciembre de 1809. Dice haber en el convento de franciscanos de Santa Clara 8 clérigos y 4 religiosos; que la población es de 25.000 vecinos, con los que bajan de los campos inmediatos. 
real cédula de 1 de octubre Fernando VII ordenaba abrir escuelas en los claustros de los conventos.

La ley de supresión de regulares, de 1837, afectó al de franciscanos de Santa Clara, pasando todos los bienes del mismo a la Inspección de Estudios para su aplicación a la enseñanza pública. ${ }^{58}$

En cuanto al convento franciscano de Santa María de los Angeles de Bayamo, fue uno de los primeros instalados por la orden en la isla (1582), después de los de Santiago de Cuba y La Habana. Nos cuenta Ismael Teste que en él existió la primeta escuela pública, fundada por fray Francisco Adán, con las limosnas del vecindario ${ }^{59} \mathrm{y}$ que funcionaba ya a finales del siglo XVI. Los franciscanos se encargaron de aquella escuela gracias a los bienes de la obra pía del capitán Francisco de Parada, hasta la conmutación de dicha obra, en 1735 , hecha a favor del convento de Santo Domingo. Sin embargo, la orden franciscana siguió teniendo lectur de latinidad durante todo el siglo XVIII y el XIX. ${ }^{60}$

A pesar de la información de Teste, de que la enseñanza primaria en el convento franciscano de Bayamo cesó en 1735, nos consta que, en 1813, había no sólo clase de latinidad sino también

58 A.H.N., Uiltramar, 31, núm. 25. El gobernador capitán general de Cuba sornete a la aprobación de Su Majestad la cesión hecha a la Inspección de Estudios de ciertos capitales acensuados procedentes del extinguido convento de San Francisco de Villa Clara. Habana, 29 de diciembre de 1854. En 1852 la Inspección había reclamado el abono de las cantidades que a cuenta de los réditos cedidos hubiesen entrado en arcas reales desde la supresión de las comunidades religiosas hasta la fecha de la donación. Ascendían a 2.834 pesos. La superintendencia se negó varias veces. El 30 de mayo de 1855 , la Corte resolvió, de acuerdo con la sección de Hacienda, que sólo se entregaran a la Comisión de Instrucción Primaria Local de Villa Clara aquellos censos o bienes procedentes del Hospicio de franciscanos, que según las cláusulas de las respectivas fundaciones deban aplicarse a la enseñanza.

59 Teste, J.: Historia eclesiástica..., tomo IV, pág. 59.

60 Ibídém, pág. 60. El capitán Parada era natural de Medina de Torres. Fue teniente de gobernador con Gonzalo Pérez de Angulo, en 1550. Falleció en mayo de 1571. Parada había instituido tres capellanías para la celebración de he fiesta de la Asunción de Nuestra Señora y un Patronato para el mantenimiento de clases de latinidad. Las mandas de Parada dieron lugar a diferentes altercados que llegaron a la excomunión de un gobernador de La Habana. 
dicha «escuela constitucional de primeras letras», por los padrones de la isla de Cuba, censo mandado hacer por el arzobispo. ${ }^{61}$

Suprimido en 1821, en cumplimiento de la ley de 1 de octubre de 1820 , por no tener el número de religiosos asignado, ${ }^{62}$ sería abierto en 1824 y nuevamente cerrado, en 1841 , cuando contaba únicamente con dos sacerdotes.

Con respecto a los franciscanos de Puerto Príncipe (Cama. güey), no tenemos dato alguno que nos permita afirmar que se dedicaran a la enseñanza primaria. En los padrones de la isla de Cuba, realizados por los párrocos (censo mandado hacer por $\mathrm{e}$ ? arzobispo en 1813), sólo se menciona que había un convento de franciscanos con ocho religiosos. ${ }^{63}$ En 1821 , como tantos otros, también sería suprimido por falta de sacerdotes. Por el informe realizado por el jefe político de Puerto Príncipe al secretario del Despacho de la Gobernación de Ultramar, con motivo de esta supresión, sabemos que el edificio conventual, aunque bastante deteriorado ofrecía «bastante capacidad» para dedicarlo a «enseñanza pública» de la que carecía esa capital. Lo que proponía en realidad era que en él se ubicara la Universidad Provincial que debía establecerse con arreglo a los planes de las Cortes. ${ }^{64}$

La orden de San Francisco contaba con dos conventos en la ciudad de La Habana: el de la Purísima Concepción, fundado en 1576 y el del Hospicio denominado de San Isidro. La construcción del edificio de la Purísima, según Teste, comenzó en 1547. Para formar a nuevos misioneros determinaron fundar una escuela que llegó a ser de las primeras de la orden en América. Sus estudios fueron los primeros de la ciudad. ${ }^{65}$

Aparte de esta información de Teste sólo tenemos noticias

61 A.G.I., Santo Domingo, 1.337.

62 A.G.I., Ultramar, 137. Carta del jefe político de Santiago de Cuba informando de la supresión y otras circunstancias. 24 de marzo de 1821.

63 A.G.I., Santo Domingo, 1.337.

64 A.G.I., Ultramar, 109. José María Zamora, intendente jefe político al secretario del Despacho de la Gobernación de Ultramar. Puerto Príncipe, 4 de noviembre de 1821. Da cuenta de lo practicado para la supresión del convento de San Francisco y subsistencia del de la Merced.

65 Teste, I.: Historia eclesiástica..., tomo IV, pág. 33. 
de que se dedicaran a la enseñanza primaria a partir de enero de 1819, como consecuencia de la orden dada por Fernando VII de que se abrieran escuelas gratuitas en los claustros de los conventos, docencia que cesaría con los cambios políticos habidos en 1820 .

Si en el primer cuarto del siglo XIX abundan las tensiones entre estos religiosos y el obispo, por problemas de relajación, secularización, etc., en la década de los treinta debían de gozar de mayor prestigio cuando el gobernador recomendaba al ministro de Hacienda, en 1838 a los franciscanos, con motivo de la orden de supresión de comunidades religiosas, considerando conveniente que se conservaran sus conventos, así como el de misioneros capuchinos. ${ }^{66}$

Según Teste, en 1531, llegó a Santiago de Cuba la misión que deseaba fundar la primera casa franciscana en la isla. Tres veces fue destruido el convento en esta ciudad, pero siempre lo volvieron a edificar mejorándolo. ${ }^{67}$

Sabemos por Bachiller y Morales que los franciscanos de Santiago de Cuba también se dedicaron a la enseñanza. En una de las notas que nos facilita, en el cuadro de la instrucción pública de la isla, según los datos reunidos por la Sección de Educación de la Real Sociedad Patriótica de La Habana, en 1836, nos dice que se educaban gratuitamente 60 niños. ${ }^{68}$

Ismael Teste también nos facilita información acerca del convento de esta orden establecido en Sancti Spíritus. Sabemos por ella que el padre Silvestre Alonso les dio a los franciscanos de esta villa

«...los necesarios recursos para la fundación del convento que, en el año de 1716, quedó instalado en un edificio con bastante capacidad para la comunidad y local apropiado para la escuela

66 Santo Domingo, 1.306. Miguel Tacón al secretario del Despacho de Hacienda. La Habana, 7 de febrero de 1838. Los únicos que se dedicaban a la enseñanza primaria eran los betlemitas, según el informe del gobernador, pero decía que sobraban colegios de instrucción primaria.

67 Teste, I.: Historia eclesiástica..., tomo IV, pág. 33.

68 Bachiller y Morales, A.: Apuntes para la historia de las letras y de la instrucción pública en la isla de Cuba. La Habana, 1936, tomo I, pág. 17. 
a la que se dedicaron desde entonces con extraordinario provecho de los alumnos». ${ }^{69}$

No tenemos motivo alguno para dudar de las palabras de Teste pero, en los archivos visitados, no hemos encontrado documento alguno que nos permita afirmar la existencia de tal escuela en el siglo XIX. Como casi todas las de su orden cerró esta comunidad en 1841 .

Tampoco tenemos noticias de que se abrieran escuelas en el último convento de franciscanos que nos falta por relatar, el de Trinidad, ni para dar cumplimiento a la orden de 1817. Su aportación a la enseñanza habrá que limitarla también al ejemplo de sus virtudes y a la docencia del catecismo y la doctrina cristiana.

Cuando se llevó a cabo la total extinción de las comunidades religiosas en la isla, en 1841 , todos los franciscanos se habían reunido en dos conventos: este de Trinidad y el de Guanabacoa; en el primero había, cuando la exclaustración, 25 sacerdotes y un hermano lego; en el segundo, 47 sacerdotes y 7 legos. La mayoría salieron a las repúblicas de Centro y Sur de América, algunos quedaron en la isla, unidos a otros sacerdotes, para las atenciones de la Iglesia. ${ }^{70}$

Veamos, por último, las referencias a la Orden Franciscana después del Concordato de 1851. La real cédula de 26 de noviembre de 1852, que restablecía las comunidades religiosas en la isla, prestaba una atención preferente a los miembros de San Franciscu; su punto IV expresaba:

"Siendo la clase de color... particularmente la que habita en los campos, la más atrasada en educación religiosa y no conviniendo para el buen régimen y disciplina de las fincas que reciban la instrucción fuera de ellas... Considerando... que... para la población agrícola puede ser más a propósito los religiosos observantes Orden de San Francisco (los que en mayor número había

69 Teste, I.: Historia eclesiástica..., tomo IV, pág. 35.

70 Ibidem, págs. 38-39. 
antes de la supresión de los conventos) he resuelto se establezca en la Península una Casa Matriz... para repoblar aquellos...). ${ }^{71}$

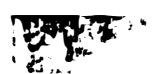

La Comisión de Instrucción Primaria de La Habana, en 1857, manifestaba ser útil y conveniente crear en los campos «leccioneros» que atendieran a la «enseñanza rutinaria» de los niños de corta edad desempeñados por padres franciscanos; fundándose en que no era posible poner una escuela de distancia en distancia muy corta, ni menos hallarse maestros que por un corto sueldo se ofrecieran a ejercer su empleo en tan aislados y remotos sitios. El gobernador de La Habana apoyaba la idea, convencido de que ésta era la única forma de conseguir los resultados que deseaban obtener, por lo que pedía a la Corte que efectivamente se estableciera la Casa Matriz para repoblar los conventos de la isla $y$ que mientras tanto destinasen algunos de los religiosos franciscanos ya existentes, con el fin de que atendieran, no sólo la instrucción primaria en los campos sino también las necesidades religiosas. ${ }^{72}$ La resolución de la Corona, de acuerdo con el Consejo Real, fue de que se solicitaran los datos estadísticos de todas las escuelas de la isla, porque partiendo la idea de la Comisión de La Habana tal vez la medida no interesara en la parte oriental; otra duda que se planteaban, sentado el caso de la conveniencia de los «leccioneros», era si se los debían asignar a comunidades religiosas o a otra clase de persona; aceptando que fuesen religiosos, opinaban, que ya estaban establecidas en la isla otras órdenes como escolapios, jesuitas y clérigos de San Vicente, cuya principal misión, además de la educación religiosa era la instrucción primaria de los niños pobres. ¿Hasta qué punto puede convenir otra nueva orden?, se preguntaban en Madrid. ${ }^{73}$

Hasta 1887 no regresarían los franciscanos a Cuba, fecha en que se estableció una comunidad en Guanabacoa.

71 A.H.N., Ultramar, 35, núm. 62.

72 A.H.N., Ultramar, 40, núm. 11. El capitán general de la isla de Cuba a la Gobernación de Ultramar. La Habana, 21 de noviembre de 1857.

73 Ibídem. Informe del Consejo Real de 14 de julio de 1858. Se comunica al gobernador que instruya nuevo expediente, después de oír a los prelados, y que lo remitiera de nuevo. 


\section{ORDEN DE PREDICADORES (DOMINICOS)}

Con cuatro conventos contaba la orden de Santo Domingo en la isla de Cuba, situados en las localidades de: La Habana, Guanabacoa, Sancti Espíritus y Bayamo.

El convento de religiosos de Santo Domingo en La Habana fue fundado en 1578. Desde que se creó la Universidad habanera, en 1728, fue esta orden la encargada de la misma, ocupando sus religiosos los principales cargos. ${ }^{74}$

Breve es el estudio que hacemos de estos dominicos porque escasas son las noticias que nos han llegado sobre su aportación a la enseñanza de las primeras letras. Sólo dos escuetos datos hemos recibido: primero, que su convento fue uno de los cuatro que se abrió en 1819 para impartir enseñanza gratuita a los jóvenes, en virtud del mandato soberano de 1817; segundo, según un informe de Gracia y Justicia de Indias, de 1826, en este convento de religiosos de Santo Domingo se hallaba establecida una escuela de primeras letras. ${ }^{75}$ Pero nada sabemos sobre matrícula, tiempo que permaneció abierta, materias de enseñanza, disciplina, etc.; incluso, es posible, que acabado el Trienio Constitucional, no estuviera en funcionamiento dicha escuela y que los datos aportados por Gracia y Justicia fueran anteriores a 1820 , que no se hubieran actualizado. ${ }^{76}$

Con respecto a la villa de Guanabacoa ya veíamos, al principio de este trabajo, cómo sus vecinos permitieron la instalación de dominicos y franciscanos en su población, con la intención de que atendiesen a la enseñanza; pero, mientras los segundos se

74 La Universidad de La Habana, durante el primer tercio del siglo XIX contó con cátedras de Teología, Cánones, Jurisprudencia, Medicina, Filosofía, Matemáticas y Latinidad.

75 A.G.I., Santo Domingo, 1.157. Estado de la isla de Cuba. Madrid, 24 de enero de 1826.

76 A.G.I., Santo Domingo, 1.306. Resumen de los regulares. La Habana, 12 de septiembre de 1837. Entre otras cargas de los dominicos consta el local que ocupa la Universidad, con sus cátedras y estudios; pero no se reflere para nada a escuelas de primera enseñanza. Con 31 sacerdotes, en 1837, era el más poblado de todos los conventos de la isla. 
dedicaron a la docencia de las primeras letras, los religiosos de Santo Domingo, (instalados en el convento de Nuestra Señora de la Candelaria), desde el primer momento se ocuparon de los estudios secundarios, enseñando latín, filosofía y teología. ${ }^{77}$

En la relación de bienes de los regulares que el Gobierno de la isla eleva a la Corte, en 1837, entre las cargas de estos reli giosos sólo figuran «las de culto y algunas misas», no hacen mención alguna a la enseñanza. Poco podían hacer al contar el conł. vento con el reducido número de cuatro sacerdotes y un lego y ser escasos sus recursos económicos, por llevar muchos años en pleito los terrenos de su propiedad y no producirles nada. ${ }^{78}$

En cuanto a los dominicos de Sancti Spíritus sabemos que el obispo Espada, en 1803, abrió una escuela en los locales del Hospicio de Jesús Nazareno, poniendo de maestro a un sacerdote del convento de predicadores de aquella ciudad, dotándole con el sueldo de 400 pesos anuales ( 300 procedentes de las rentas de dicho Hospicio y los 100 restantes de los Propios del cabildo). Numerosas fueron las críticas que recibió el prelado por disponer: de los fondos de Propios del Ayuntamiento y por la forma de elección del maestro, sin preceder información de vida y costumbres, ni el examen correspondiente por el conocimiento que de la persona elegida tenía el diocesano. ${ }^{79}$

Pocos datos hemos encontrado acerca del funcionamiento de esta escuela pero, todavía en 1837, entre las cargas de los domi-

77 A.G.I., Ultramar, 13. Por poder, la Justicia, Ayuntamiento y procurado: general de Guanabacoa, hacían presente a Su Majestad el beneficio que habian conseguido en la villa con haber enseñado por espacio de 23 años la lengua latina, Francisco Zamorano, religioso de la Orden de Predicadores. La Habana. 24 de abril de 1804.

A.H.N., Ultramar, 11, núm. 12. Expediente sobre establecer en el convento de predicadores de Guanabacoa una cátedra de Filosofía. Carta del capitán general de Cuba al secretario de Despacho de la Gobernación de Ultramar. 23 de enero de 1840 .

78 A.G.I., Santo Domingo, 1.306. Bienes de los regulares. La Habana, 12 de septiembre de 1837.

79 A.G.I., Santo Domingo, 1.125-A. Real cédula al gobernador de La Habana comunicándole haberse aprobado el nombramiento de maestro de primeras letras y establecimiento de escuela en la villa de Sancti Spíritus. San Lorenzo, 24 de noviembre de 1807. 
nicos del convento de Sancti Espíritus, figuraban «los sueldos y gastos de una escuela gratuita de primeras letras y una clase de latinidad»; disponiendo para ello, como producto de sus bienes, de 930 pesos anuales. ${ }^{80} \mathrm{La}$ comunidad estaba formada por dos sacerdotes.

Finalmente, en el convento de la Asunción de Bayamo, de los padres dominicos, como en otros de su orden, también se impartieron estudios secundarios, teniendo abiertas cátedras de Latinidad, Retórica, Filosofía, Teología, Escolástica, Dogmática y Moral, si bien carecían de habilitación para dar grados. ${ }^{81}$

Igual que ocurría en Guanabacoa, al coincidir en esta villa franciscanos y dominicos, los primeros se dedicaban a la enseñanza primaria mientras los segundos impartían estudios secundarios.

Se fundó este convento de Bayamo, hacia 1740, con la conmutación de la Obra pía de Francisco de Parada. A cambio de la fortuna dejada por dicho señor, se comprometían a tener escuelas gratuitas primarias, de Latín, Melchor Cano, Filosolía y Teología. El 10 de abril de 1826, don Manuel de Berdecie solicitaba que se cumpliera la voluntad del fundador; aunque él lo único que buscaba es que se socorriera a su familia porque se hallaba «en la mayor indigencia», era evidente que, al menos en lo de impartir enseñanza primaria, los religiosos no llevaban a efecto las obligaciones que se habían señalado. ${ }^{82}$

80 A.G.I., Santo Domingo, 1.306. Bienes de los regulares. La Habana. 12 de septiembre de 1837.

81 A.G.I., Santo Domingo, 1.154 y Ultramar, 366. Instancia de fray Manuel Antonio Caballero, prior del convento de la Asunción, a Su Majestad. Bayamo, 16 de agosto de 1803. Se queja de los perjuicios que resultaban a los jóvenes de Bayamo tener que ir a La Habana para seguir la carrera, pues se retrotraían de estudiar en su convento porque consideraban infructuoso el esfuerzo. Suplicaba que le dispensaran a su convento la gracia de habilitación de estudios en los mismos términos que se le había concedido al colegio seminario de Santiagó de Cuba.

A.G.I., Santo Domingo, 1.155-A. Al rector y Claustro de la Universidad de La Habana, a la Audiencia de Cuba y al gobernador de La Habana, se les ordena informen sobre la pretensión del prior del convento de dominicos de Bayamo. Aranjuez, 30 de marzo de 1805.

82 A.G.I., Ultramar, 4. Consejo de Indias, 21 de octubre de 1826. Se remite el. asunto al arzobispo de Cuba para que informe. 


\section{Capuchinos}

El colegio de capuchinos de La Habana, único existente en la isla de Cuba, fue instalado provisionalmente (y siempre estuvo), en el Oratorio de San Felipe Neri, en 1784

Las obligaciones de los religiosos de esta orden eran atender a la gente que asistiera a aquella iglesia para recibir los Sacrar mentos, confesar enfermos, auxiliar moribundos y misionar por la isla. Nunca abrieron escuela de primeras letras, ni cátedras de segunda enseñanza, por lo que su docencia se limitaba al ejemplo que pudieran dar y a la doctrina cristiana.

Dos problemas fundamentales tuvo esta orden, en la capital de la isla cubana, durante su tiempo de permanencia: primero, el escaso número de religiosos que siempre tuvo y que les impedía cumplir adecuadamente con su cornetido, así como el de poder enviar misioneros suficientes a las dos Floridas; 3 las quejas continuadas de miembros de la comunidad contra los procedimientos y conducta del obispo de La Habana, Juan José Díaz de la Espada. ${ }^{84}$

83 A.G.I., Ultramar, 13. En 1803 el Consejo dio licencia a fray José Sayatón, religioso lego capuchino en La Habana, para que volviese a su provincia de las Dos Castillas. El gobernador de La Habana contestó que no podía llevarse a efecto la licencia por el corto número de religiosos. Se pide desde la Corte que se informe del número de religiosos que hay y el que se necesita, a lo que el prefecto contestó que existían siete sacerdotes, de los que uno era simple y tres inútiles por achaques y ancianidad; cuatro legos: uno ciego, otro de 74 años (portero) y otro --Sayatón--. que tiene licencia para regresar a España. Que necesitaba 12 sacerdotes y el prelado para dentro de los muros y cuatro más para las Dos Floridas (donde sólo existían dos) y tres legos: limosnero, cocinero, etc.

A.G.I., Ultramar, 367. El Consejo de Indias informaba a la Corona que era conforme con que se concediera al colegio de capuchinos de La Habana una misión de 16 religiosos y 3 legos.

A.G.I., Santo Domingo, 1.155-B. El vicario general de capuchinos pedía colectar cinco religiosos sacerdotes y dos legos para La Habana por contar, dicho colegio, con sólo siete sacerdotes, tres legos y dos donados, Madrid, 24 de agosto de 1814. (El envío de los 16 sacerdotes y tres legos, al parecer no se había efectuado).

A.G.I., Santo Domingo, 1.306. En el resumen de los bienes de los regulares, de 1837, consta que esta comunidad estaba formada por siete sacerdotes y dos legos.

84 A.G.I., Ultramar, 370. Fray Bruno de Samaniego, residente en el convento de capuchinos de La Habana, se queja de los procedimientos del obispo con los individuos del colegio de su Orden. La Habana, ¿9 de agosto de 1814. El Consejo estimó que tenían razón los capuchinos y que se debía encargar al 


\section{Mercedarios}

A comienzos del siglo XIX dos conventos de padres mercedarios había en la isla de Cuba: uno en La Habana y otro en Puerto Príncipe.

Las cosas no debían marchar muy bien por el de la capital habanera cuando ellos mismos solicitaban a la Corte que se redujera su número hasta llegar al de la primitiva fundación, porque las rentas no daban para el sustento de todos y por tanto debían buscarlo por otros medios en detrimento de la regla monástica. ${ }^{85}$

Varios documentos encontrados en los archivos visitados ponen de manifiesto la tibieza y relajación de algunos de estos religiosos de La Habana, de los que no nos vamos a detener mucho porque no nos consta que tuvieran una participación muy activa en la enseñanza. Ya veíamos la aportación negativa del mercedario Francisco de Paula Chacín, que utilizaba el púlpito para proferir

obispo se abstuviera de molestar a los religiosos con suspensiones ni otras penas semejantes. Madrid, 26 de septiembre de 1814. El obispo de La Habana, en 14 de abril de 1815, dice no haber hecho otra cosa que cumplir con su deber; que las quejas eran infundadas, que silenciaban las causas y circunstancias por las qule dio sus disposiciones; exponía los abusos de los religiosos, la falta de disciplina monástica, de vida claustral, etc. En otro informe del obispo a don Esteban Varea, fechado en La Habana a 11 de julio de 1815, hablaba el prelado de las «intrigas». «desobediencia absoluta» y «siniestras intenciones del capuchino Bruno de Samaniego... so la capa de celo en defensa de los derechos o privilegios regulares...».

A.G.I., Ultramar, 372. Quejas de Tomás Berrón, de la Orden de Capuchinos.

A.G.I., Ultramar, 3. El Consejo de Indias, en 20 de mayo de 1817, proponía mandar al obispo de La Habana, la orden de que tratara a los religiosos con suavidad.

A.G.I., Ultramar, 371. Se le participa al prelado lo resuelto sobre las quejas dadas por los capuchinos y otros religiosos.

85 A.G.I., Ultramar, 394. Consejo de Indias, 17 de septiembre de 1798. Erigido en La Habana, en 1774, con ocho sacerdotes y dos legos, en 1784 tenía ya 27 sacerdotes por lo que se acordó la supresión de ocho; lejos de cumplirse. en el 96 eran 37, sin contar con los que se esperaban de Santo Domingo. El visitador reformador, en 1784, propuso que por cada dos religiosos que murieran o faltasen se admitiría un novicio, por la necesidad de individuos jóvenes. Pedía a la Corte, en 1798, que destinara un «sujeto de conocida providad y literatura que entendiera en arreglar y reformar la disciplina monástica decaída». Salían del claustro y se empleaban en servir capellanias en los ingenios o pretendían curatos. Opinaban que los reformadores enviados en 1774 y 1784 sólo sirvieron para ocasionar inmensos gasios y empeñar a los conventos, dejándolos en su ausencia en al mismo estado de tibieza y relajación. 
expresiones sediciosas contra la metrópoli. No debemos de tomar la excepción como regla general y por tanto tenemos que pensar que otros muchos compañeros aprovecharon su influencia sobre la población para instruirlos, si no en las primeras letras, sí al menos en doctrina cristiana.

Cuando en octubre de 1817 Fernando VII ordena que se abran escuelas en los conventos de religiosos, uno de los que se ofreció a dar enseñanza en La Habana fue el de la Merced. Desconocemos el número de alumnos y demás circunstancias de esta escuela, pero poco pudo influir en la instrucción de los jóvenes, debido a que comenzaron a impartir la docencia en enero de 1819 y al año siguiente lo dejaban, a consecuencia del cambio político habido en España.

Mucho se había reducido su número, en 1820, cuando fue anulado el convento en virtud de la orden de supresión de monacales y arreglo de regulares (eran suprimidos los que contasen con menos de doce individuos, a gran parte de ellos se les había concedido la secularización). Al solicitar al Gobierno Supremo la cuota alimentaria, los sacerdotes mercedarios, exponían que sus propios estatutos prohibían el trabajo de mano y sólo se dedicaban a ejercicios devotos, a la oración, enseñanza y educación de la juventud y que incluso para esas actividades tenían problemas por su avanzada edad y sus achaques. En lugar de concedérseles la pensión solicitada, se les mandó unirse al convento de su orden situado en Puerto Príncipe, y que al individuo que no le acomodase, que solicitara la secularización. ${ }^{86}$

Concluido el Trienio Constitucional (1820-1823), las padres mercedarios vuelven a su convento de La Habana. Pero, el espíritu religioso de los mismos no sería el apropiado cuando, en 1828, el general de la orden de la Merced, Juan José de Tejada, solicitaba permiso a la Corte para enviar a La Habana dos religiosos (visitador y secretario), haciendo presente su necesidad para la conservación y reforma de los dos conventos existentes en la isla

86 A.G.I., Ultramar, 396. Expediente sobre reclamación de congrua por los sacerdotes del convento de la Merced (1821-1823). 
«por el desorden a que habían venido por efecto del trastorno de los tres años del abolido sistema constitucional». ${ }^{87}$

En 1837, fecha de su supresión definitiva, el convento mercedario de La Habana, tenía 16 sacerdotes y cuatro coristas. Sus bienes consistían en 18 casas en la ciudad y 15 accesorias, cuyos ingresos podían calcularse en unos 1.000 pesos mensuales y en cuanto a cargas sólo consta que tuvieran diversas misas y fiestas del culto en su iglesia, pero nada de enseñanza. ${ }^{88}$

Con respecto al convento de la Merced de Puerto Príncipe, fue el único que quedó en esta ciudad durante el Trienio Liberal, al suprimir el de San Francisco. Se hallaba comprendido, para su subsistencia, en el caso del artículo 17 de la ley de supresión de 25 de octubre de 1820 , por contar con 13 religiosos ordenados in sacris. Además, según manifestaba el intendente jefe político interino, José María Zamora, al secretario del Despacho de la Gobernación de Ultramar, era notorio que en este convento

(....se había enseñado y se enseñaba Gramática, Filosofía y Teología, habiendo clases públicas de estas ciencias, precedidas por religiosos del mismo, en términos que dicho convento puede gloriarse de que a él le deban innumerables empleados de todas clases, las luces y conocimientos que poseen en su carrera». ${ }^{89}$

Se trataba, por tanto, de enseñanza secundaria

Poco duró la alegría de estos padres mercedarios. Al cambiar el intendente jefe político interino, el nuevo -Pedro Ruiz de Ortega-, escribió dos cartas dirigidas, una a las Cortes y la otra al Ministerio de Ultramar, con fecha 26 de noviembre de 1822, en las que comunicaba que habiéndose disminuido el número prefijado por la ley, por haber sobrevenido algunas secularizaciones,

87 A.G.I., Ultramar, 42. Conformándose el rey con el parecer del Consejo de Indias, de 20 de noviembre de 1828, se sirvió acceder a lo propuesto. Madrid. 24 de enero de 1829.

88 A.G.I., Santo Domingo, 1.306. Bienes de los regulares. La Habana, 12 de septiembre de 1837.

89 A.G.I., Ultramar, 109. José María Zamora al secretario del Despacho de la Gobernación de Ultramar. Puerto Príncipe, 4 de noviembre de 1821. Con fecha 14 de agosto de $18 \dot{2} 2$ se aprobó la subsistencia de este convento de la Merced.

Tomo XLVIII 
había considerado ser su obligación el suprimirlo, a pesar de las reclamaciones que había hecho su prelado. ${ }^{90}$

Las razones expuestas para la supresión por el intendente jefe político debían de ser ciertas, pero tal vez actuó con saña contra los mercedarios en su decisión de eliminarlos. En un informe de la Diputación Provincial de La Habana, se exponían varios puntos negativos sobre Pedro Ruiz de Ortega: se le tachaba de «porte poco conforme»... «por separarse de la obediencia debida a la Superintendencia cuya superioridad no le place reconocer». ${ }^{91}$ Con la vuelta al poder del gobierno absolutista de Fernando VII, se acaba este litigio.

Bachiller y Morales, en el cuadro sobre instrucción pública de la isla en 1836, según los datos de la sección de Educación de la Sociedad Económica de La Habana, nos dice que los mercedarios de Puerto Príncipe educaban a 40 niños. Nos inclinamos a que fueran de primeras letras aunque no especifica nada. ${ }^{92}$

En 1837, en la evaluación de sus bienes, con motivo de la supresión definitiva, consta que había en este convento 11 sacerdotes y un lego. Sus cargas se limitaban a «varias misas y fiestas del culto». Por esa fecha, al parecer, ya tampoco impartían aquellas enseñanzas de que nos hablara el jefe político en 1821 , ni las manifestadas por Bachiller y Morales. ${ }^{93}$

\section{Agustinos}

La Orden de San Agustín sólo tenía un convento en la isla de Cuba, situado en la capital de La Habana.

90 Ibídem. Según exponía el jefe político, uno llevaba ya dos años fuera del convento, por enfermedades y edad octogenaria; otro llevaba 18 años demente; dos habian pedido secularización. El 1 de agosto de 1822 resolvió su supresión. El prelado del convento, lejos de presentarse a la Comisión de Inventario, como se le había ordenado, planteó una querella y trató de conmover los ánimos contra el jefe político.

91 A.G.I., Ultramar, 110.

92 Bachiller y Morales, A.: Apuntes..., tomo 1, pág. 17, nota primera.

93 A.G.I., Santo Domingo, 1.306. Bienes de los regulares. La Habana, 12 de septiembre de 1837 . 
Pocas noticias han llegado hasta nosotros de la participación agustina en la instrucción habanera; abundan, sin embargo, los documentos en los que al menos se duda de la conducta de algunos de estos religiosos. ${ }^{94}$

En cuanto al tema que nos interesa, el de la enseñanza, sabemos que en 1817 la Sociedad Económica de La Habana estaba haciendo las gestiones oportunas para establecer una escuela gratuita en el convento de San Agustín, según el método de Lancaster. Tal proyecto no se llevó a cabo al disponer el soberano que se abrieran escuelas en los conventos de religiosos, pero sí que fue este claustro agustino uno de los cuatro designados para la enseñanza gratuita a la juventud de La Habana y que comenzaría la docencia en enero de 1819.

Como los sacerdotes de otros muchos conventos, serán suprimidos en 1820 , reinstalados en 1823 y desaparecerán definitivamente en $1841 .{ }^{95}$

\section{JUANINOS}

La Orden Hospitalaria de San Juan de Dios contaba con dos conventos en la isla: uno en La Habana y otro en Puerto Príncipe. En ambos, las obligaciones de sus religiosos se limitaban al sostenimiento de los hospitales de caridad. No tenemos dato alguno que nos permita afirmar que impartieran algún tipo de enseñanza.

94 A.G.I., Ultramar, 367. Expediente sobre la secularización del agustino Manuel de Oliva. (Se fugó de La Habana y fue al Consejo de Indias, lo apresaron los ingleses, pidió refugio a España, se le ordenó volver a Cuba y que vigilaran su conducta. 1807-1808).

A.G.I.,Ultramar, 397. El prior del convento de San Agustín de La Habana, en 1807, refiere al Consejo, los ultrajes que ha recibido del obispo hasta haberle, privado de la prelacía y funciones sacerdotales (supresión de licencias de confesar y predicar).

Hay otro expediente sobre la desobediencia al obispo de fray José María Aparicio, prior del convento de San Agustín, presentado por el apoderado del obispo.

95 A.G.I., Ultramar, 397. Amplio expediente sobre la entrega de sus propiedades al prelado y religiosos de la orden de San Agustín. Comenzó dicha entrega el 26 de abril de 1824 y concluyó el 28 de mayo de 1824 .

A.G.I., Santo Domingo, 1.306. En 1837, la onden Agustina en La Habana contaba con: nueve sacerdotes, seis coristas y tres legos. 
La real cédula de 26 de noviembre de 1852 mandaba que desaparecida en la península esta orden y faltando casi todos sus individuos en la isla de Cuba, se encargasen de los hospitales las Hermanas de la Caridad.

\section{PADKes paÚles}

Los primeros religiosos de la Orden de San Vicente de Paúl llegaron a La Habana el 21 de enero de 1847, según nos narra Ismael Teste. Durante varios años vivieron, dos de estos sacerdotes, en una casa alquilada, cerca de la Casa de Beneficencia y del Hospital de San Lázaro, cuyas capellanías atendían. ${ }^{96}$

La real cédula de 26 de noviembre de 1852 , en su punto primero, disponía, que teniendo en consideración los servicios a la Iglesia de estos clérigos, y la obligación por su regla de dedicarse a la enseñanza religiosa y misiones, se abrieran dos casas de esta Orden, una en Santiago y otra en La Habana, en alguno de los conventos suprimidos, que el gobernador, de acuerdo con el intendente, tuviese por conveniente designar, siendo obligación de aquéllos encargarse en la enseñanza, régimen y disciplina de los seminarios conciliares, con el beneplácito de los diocesanos, cuya suprema dirección e inspección debían conservar siempre. ${ }^{97}$

Pero no tuvo efecto este apartado primero de la real cédula. Ya veremos cómo el arzobispo de Cuba era partidario de encomendar la enseñanza en los seminarios a la Compañía de Jesús.

\section{PAdRES ESCOLAPIOS}

En 1815 varios vecinos de Nuestra Señora de Guadalupe, extramuros de la capital de La Habana, solicitaban a la Corte la permanencia en aquella localidad de fray Gabriel de la Guardia,

96 Teste, I.: Historia eclesiástica.... tomo IV, pág. 263. Se trataba de los padres Vila y Francisco Boch. Desembarcaron en compañia de las primeras Hijas de la Caridad, que también llegaron por primera vez a Cuba.

97 A.H.N., Ultramar, 35, núm. 62. 
religioso de las Escuelas Pías de Getafe, que estaba dedicado a la enseñanza pública, así como la remisión desde la península de otros de su Orden para el mismo fin. Exponían en su escrito que dicho sacerdote, estimulado por los deberes sagrados de su «instituto» y movido por la necesidad de tantas familias que carecían de educación y de medios para optar a ella, había abierto una escuela gratuita para niños pobres a la que acudió tan elevado número de alumnos que pronto no bastó su persona para desempeñar las tareas educativas por lo que tomó, a sus expensas, los ayudantes necesarios asalariados. Los niños, según dicho documento, eran instruidos por el religioso

«...en el santo temor de Dios, doctrina cristiana, leer, escribir, contar, gramática castellana y latinan. ${ }^{9 \%}$

El 4 de junio de 1816, desde Madrid se comunicaba la orden de que todos los eclesiásticos, seculares y regulares, que se hallaban en la isla de Cuba emigrados de la península, volviesen a ella para reunirse en sus conventos. Informado fray Gabriel de la Guardia, por el prelado, de dicho mandato, recurrió al capitán general excusándose de realizar el viaje por: hallarse enfermo, según acreditaba por certificaciones médicas; por estar «agitando» la fundación de unas capellanías y, por último, porque estaba pendiente de la resolución soberana de la instancia del Ayuntamiento de aquella capital para que permaneciese en ella dedicado a la enseñanza de la juventud. No habiendo considerado justos, el obispo de La Habana, los pretextos del padre la Guardia, el capitán general le señaló dos meses para su salida de la isla; plazo que después fue ampliado, sin fijar fecha exacta, ordenándole saliera cuando estuviera restablecido. Por otro expediente, que corría

98 A.G.I., Ultramar, 372. Instancias de varios vecinos de Nuestra Señora de Guadalupe a Su Majestad. 18 de marzo de 1815. También exponían que la población no bajaba de 30.000 vecinos. Jas dificultades de comunicación con La Habana, la pobreza de sus habitantes, que vivían del trabajo diario. Hacían un elogio encendido de fray Gabriel de la Guardia, porque, según ellos, «el parvulito pobre pobre, el huérfano desdichado recogido caritativamente en la propia casa de su morada encuentra allí con la instrucción un padre que lo mantiene y un ayo que lo eduque». 
paralelo, a este religioso se le terminaría autorizando para que pidiera la secularización. ${ }^{99}$

No volvemos a encontrar información alguna acerca de los escolapios en la isla de Cuba hasta 1835 en que el Ayuntamiento de Puerto Príncipe solicitaba real permiso para que fueran de la península tres padres de esta Orden, para que se dedicaran a la enseñanza de la juventud. Manifestaban que serían bien acogidos, proporcionándoles sus habitantes cuanto pudieran necesitar mientras conseguían establecer formalmente el colegio. Añadían que incluso había un vecino, que por modestia no quería se supiera su nombre, que se comprometía a costear el transporte de los tres escolapios, que al parecer se hallaban dispuestos a ir, desde Barcelona a Nuevitas, siempre que se les concediera la licencia necesaria. ${ }^{100} \mathrm{La}$ resolución de la Corona fue suspender el expediente promovido por el Ayuntamiento, hasta que se presentase el Plan General de Enseñanza. ${ }^{101}$

La real cédula de noviembre de 1852 que marcaba, como ya hemos visto, las consecuencias para Cuba del restablecimiento de las relaciones con la Santa Sede, a raíz del concordato de 1851, señala, en su punto II, que para llenar en La Habana y Santiago de Cuba el vacío dejado por la falta de padres betlemitas, se restablecieran dos casas de padres escolapios, en cuyos colegios, además de la enseñanza primaria para las clases pobres, pudieran recibir las acomodadas una esmerada educación religiosa.

99 A.G.I., Santo Domingo, 1.155-B. El capitán general de Cuba informa al Consejo haber comunicado la orden de 4 de junio de 1816. La Habana, 4 de. diciembre de 1816.

A.G.I., Santo Domingo, 1.290. José Cienfuegos a Pedro Ceballos (Gracia y Justicia). Remite testimonio de lo obrado sobre la solicitud de permanecer allí ef padre Gabriel de la Guardia.

100 A.G.I., Cuba, 2.350-A. El teniente gobernador de Puerto Príncipe al gobernador de La Habana, Miguel Tacón. Acompaña testimonio del acta celebrada en el Ayuntamiento, el 14 de febrero de 1835. Puerto Príncipe, 16 de febrero de 1835. El vecino que hacía tan laudable oferta era el comerciante don Esteban. Riverol. El 29 de abril del mismo año, el gobernador habanero dirigía al Ministerio del Interior la solicitud del Ayuntamiento.

101 Ibídem. El gobernador de La Habana all ministro del Interior; comunica haber trasladado al teniente gobernador de Puerto Príncipe la real orden de 13 de junio de 1835, por la que la Reina Gobernadora había determinado suspender la solicitud del Ayuntamiento de Puerto Príncipe. La Habana, 20 de agosto de 1835. 
En 1856 los escolapios Bernardo Collazo y Agustín Botey viajaban a la isla de Cuba para poner en práctica las diligencias más convenientes que dieran cumplimiento a la real cédula de 1852 mencionada. Puestos en contacto con autoridades civiles y eclesiásticas fijaban las bases y condiciones que por ambas partes habrían de observarse. ${ }^{102}$

El 30 de marzo de 1857, el capitán general de la isla, José de la Concha, pedía informes a los prelados de La Habana y Cuba acerca de la orden religiosa a la que se debían de encargar las escuelas normales y los centros de segunda enseñanza, según el número de padres que pudiera disponer cada congregación. El obispo de La Habana, el 4 de abril del mismo año, contestaba estar feliz y conforme con el establecimiento en aquella capital o en Guanabacoa de un centro de formación de maestros regido por los escolapios y era partidario de encargar también a esta orden y no a los jesuitas la enseñanza secundaria de Puerto Príncipe «tanto por el número como por otras razones de conveniencia», (razones que no especifica). Con respecto al arzobispo de Cuba, Antonio María Claret, el 6 de abril de 1857, contestaba al Gobierno de La Habana, haberle llenado de satisfacción la idea acertada de crear una escuela normal en cada departamento; opinaba debía situarse en Santiago de Cuba; en cuanto al punto de si veía bien poner a los escolapios en Puerto Príncipe, decía que sí... y también con el tiempo, otro colegio en Santiago y otro en Bayamo. Como podemos observar, estos religiosos, gozaban de mucha aceptación. Los padres de la Compañía de Jesús, además de su colegio de La Habana, quería el santo prelado que se hicieran cargo de los seminarios conciliares. ${ }^{103}$

No obstante fijar, la real cédula de 1852, a La Habana y Santiago de Cuba como ciudades donde había que establecer las

102 A.H.N., Ultramar, 35, núm. 62. Jacinto Feliu, comisario apostólico, al ministro de Estado. Valencia, 21 de agosto de 1857. Le comunica el traslado de ambos religiosos y le dice haber llegado el caso de mandar expedir el corres. pondiente pasaporte a nueve sacerdotes destinados a colegios instalados en Guanabacoa y Puerto Príncipe, y de cinco operarios o legos con destino al servicio de ambos.

103 A.H.N., Ultramar, 50, núm. 1; Expediente sobre creación de la Escuela Normal en La Habana. 1857. 
Escuelas Pías, fueron Guanabacoa y Puerto Príncipe las localidades donde primero se instalaron. En 1857 se envió la primera remesa de religiosos que estuvo compuesta por nueve sacerdotes y cinco legos. ${ }^{104}$ Tres años después - 1860-, el comisario apostólico comunicaba a la Dirección de Ultramar, que era muy reducido el número de profesores destinados a la enseñanza en sus dos colegios de la isla, por lo que era preciso mandar alguno más; suplicaba permiso para trasladar a tres religiosos y un lego. ${ }^{105}$

Por el artículo 184 del Plan General de Estudios, aprobado por real orden de 15 de julio de 1863 , se manda crear dos escuelas normales en la isla, una para el departamento Oriental y otra para el Occidental. Con respecto a la Normal de la parte Occidental no había problemas porque los escolapios se encargarían de la enseñanza en la misma, la cual tendría el carácter de central de la isla. Faltaba organizar la de la parte Oriental. Por mandato real de 1 de octubre de 1863 se comunicaba al comisario apostólico de las Escuelas Pías que manifestara si podía dedicar cinco o seis individuos de la orden a la enseñanza en el nuevo establecimiento en Santiago de Cuba, bien enviándolos de la península o de alguna de las casas existentes en la isla. El comisario contestaría, 15 días después, no haber inconveniente a facilitarlos siempre y cuando se habilitara local para recibirlos. ${ }^{106}$ El 24 de octubre de 1863 , el ministro de Ultramar comunicaba al gobernador de la isla todas

104 A.H.N., Ultramar, 35, núm. 62. Sacerdotes de las Escuelas Pías que pasaron a Ultramar: José Zofre, Manuel Espinosa, Ramón Querolt, Francisco Cleveh, Blas Gómez. Pablo Trías, Antonio Perpiñá, Faustino Míguez y Luciano Solis González. Operarios: Joaquín Biosca, Román Pecardón, Pelegrín Guillén, Jayme Faja y Pedro Díaz.

105 Ibídem. Jacinto Feliú a Uliramar. Valencia, 4 de agosto de 1860. Los sacerdotes para los que solicitaba permiso eran: Bernardo Collazo (que ocupaba el cargo de rector del colegio de Guanabacoa), Modesto García y Angel Martí. Miguel Boada se llamaba el lego. La Reina les concedió el permiso el 18 de agosto de 1860 .

106 Ibidem. Jacinto Feilu a Ultramar (Ministerio). Valencia, 15 de octubre de 1863. El comisario dice haber recibido el oficio de 1 del corriente, incluyéndole seis ejemplares del Plan de Estudios de la isla de Cuba, en el que la Reina le manifiesta su voluntad de que se establezca en Santiago de Cuba una escuela Normal a cargo de las Escuelas Pías. Expone que aunque de las casas de Guanabacoa y Puerto Príncipe no podía «distraer» ningún individuo, por estar los precisos, no faltarían operarios en cuanto tuvieran preparado el local y todo lo necesario para la Escuela Normal. 
las gestiones realizadas, con respecto a la Normal de Santiago de Cuba, con objeto de que dictara las medidas necesarias para preparar la instalación de la referida escuela y de proveer de albergue a los correspondientes padres escolapios.

Nuevas remesas de religiosos de esta orden saldrían para Guanabacoa y Puerto Príncipe pero, la Normal de Santiago de Cuba al término de nuestro estudio - 1868-, todavía no estaba en funcionamiento. ${ }^{107}$

Como ya hemos indicado anteriormente, los escolapios, gozaban de mucho prestigio en tierras cubanas. El gobernador de $\mathrm{La}$ Habana, José Gutiérrez de la Concha, en 1859, comunicaba al ministro de la Guerra y Ultramar el resultado de los exámenes de la escuela normal de Guanabacoa, los cuales tuvo el honor de presidir; decía haber quedado muy sorprendido por los adelantos que habían hecho en un año escaso que tenía el centro de existencia y que este resultado se debía

(....al celo, inteligencia y laboriosidad de los Padres Escolapios que han empleado sus tareas con el ardor propio de personas que hacen de la enseñanza un voto religioso...).

Consideraba, dicha autoridad, que eran acreedores a toda benevolencia y que se debía proteger por todos los medios el desarrollo en la isla de tan importante institución. Proponía que la protección más eficaz y activa podría ser crear un seminario en Guanabacoa en el cual pudiesen dar la enseñanza primaria y secundaria porque, estos padres, habían sido perfectamente recibidos y aceptados en la opinión pública. En Puerto Príncipe los escolapios se dedicaban a la secundaria y en Guanabacoa a la preparación de los maestros y a la enseñanza primaria; pero, según opinión del general

107 Ibídem. El 25 de octubre de 1863 el comisario apostólico pedía penmiso para enviar a la isla de Cuba a los sacerdotes: Domingo Lancia, Domingo Moreno, Francisco Romero y Francisco Alberti; y ad lego José Gresa.

El 19 de agosto de 1866, el vicario general manifestaba que saldrían para Guanabacoa y Puerto Príncipe: Domingo Fita, Domingo Moreno (otra vez, tal vez no había salido la anterior), Joaquín Campos, Francisco Lozano y José María Hernández. 
Concha, se debía de dar también la secundaria, porque multitud de gente se había presentado solicitando la admisión de su hijos y se retiraban con desconsuelo, al ver que no podían ser atendidos. Exponía el gobernador:

"Si fuera posible crear en un mes un seminario capaz de 200 plazas, todas quedarían cubiertas en 24 horas... El día que tuvieren medios materiales (los escolapios de Guanabacoa) para recibir discípulos se llenarían instantáneamente sus colegios como se llenó el de Puerto Príncipe apenas quedó abierto y debe tenerse muy en cuenta que cada alumno de éstos es una inteligencia y un corazón arrancados a la influencia norteamericana porque de seguro no irían a buscar su educación fuera del país si en él la encontrasen apropiada y menos costosa). ${ }^{108}$

\section{Jesuitas}

Nos consta que en la isla de Cuba las virtudes de los religiosos de la Compañía de Jesús, en materia de enseñanza, eran altamente valoradas en el siglo XVIII. ${ }^{109}$ Con cierto pesar debieron acoger los cubanos la noticia de su supresión, en el reinado de Carlos III, a pesar de que con sus cuantiosos bienes se financiaban, en parte, una serie de establecimientos educativos y de caridad. ${ }^{110}$

108 A.H.N., Ultramar, 50, núm. 1. José de la Concha al ministro de la Guerra y Ultramar. La Habana, 9 de febrero de 1859.

109 A.G.I., Santo Domingo, 2.231. Por poner un ejemplo, desde La Habana, el 28 de junio de 1749, el obispo de Cuba, solicitaba a Juan Antonio Valenciano. la fundación de un Colegio de la Compañía de Jesús para Puerto Príncipe, por distar mucho de La Habana y ser costoso el mantenimiento de los estudiantes en la capital. El informe de la villa, tanto del cabildo como del estamento eclesiástico, era favorable. Donaban los vecinos 40.000 pesos para su dotación más 12.000 para su fábrica. Hacían un panegírico de las virtudes que adornaban a los jesuitas.

110 A.G.I., Ultramar, 118. Real cédula de 11 de julio de 1772 , dispositiva de la aplicación que debía hacerse de los bienes y acciones de los jesuitas, después de cubiertas las cargas de justicia que tenían sobre sí, a saber: a la Universidad de La Habana 1.000 pesos; a los niños expósitos, 3.000 pesos; a la Casa de Recogidas 1.500; al hospital de San Francisco de Paula, 1.000; al de San Lázaro, 2.000; al Colegio Seminario, 3.000; para la cárcel, 500; otros 500 al hospital de San Juan de Dios, y para el colegio de niñas de San Francisco de Sales, 650 pesos.. 
Con el regreso al poder de Fernando VII, en 29 de mayo de 1815 , decretó el restablecimiento de los regulares de la Compañía de Jesús en todos sus dominios, así de España como de Indias, estableciéndose para el aumento de miembros de dicha Compañía una Junta con privativa autoridad y facultades en el asunto. ${ }^{111}$ Por otra real orden de 26 de septiembre de 1824 se le comunicaba al gobernador de La Habana que entregara al superior de la Compañía de Jesús todos los bienes a ella pertenecientes. ${ }^{112}$

Pero los enfrentamientos existentes entre los gobiernos liberales de Isabel II y la Iglesia serán la causa de que no se establezcan centros de enseñanza jesuíticos en la isla de Cuba hasta la segunda mitad de la centuria. Firmado el concordato con la Santa Sede (1851), la real cédula de 26 de noviembre de 1852 encargaba especialmente la educación secundaria a los seguidores de San Ignacio, que establecieron su primer colegio (de esta segunda etapa), en el convento de Belén de La Habana.

No vamos a detenernos en hablar del colegio jesuítico de la capital habanera, cuyos estudios se declararon válidos para ser admitidos sus cursantes en Facultad Mayor de la Universidad, por real orden de 30 de septiembre de $1856,{ }^{113}$ por tratar nuestro trabajo de la enseñanza de las primeras letras.

Sin embargo, tenemos la obligación de comentar con más detalle el centro educativo que, a cargo de los padres de la Compañía, se creó en Sancti Espíritus, en 1862, por impartir en el mismo tanto la primera como la segunda enseñanza. La idea de establecer este colegio, bajo dirección jesuítica y en la misma forma que el

111 A.G.I., Santo Domingo. 1.290. Echeverri, gobernador interino, a Pedro Ceballos. La Habana, \&l de octubre de 1816. Dice haber recibido la orden sobre lo dispuesto por Su Majestad en decreto de 29 de mayo de 1815.

A.G.I., Ultramar, 3. Constan las libranzas giradas por el presidente de la Junta de res:ablecimiento de los jesuitas. Consejo de Indias, 27 de mayo de 1819.

112 A.G.I., Santo Domingo, 1.299. Vives al secretario del Consejo Supremo de Indias. La Habana, 1 de febrero de 1825 . Acusa el recibo de la orden de 26 de septiembre de 1824 .

113 A.H.N., Ultramar, 35, núm. 45. El Ministerio de Fomento, en 4 de mayo de 1857, picle informe al Ministerio de Estado (Ultramar) sobre el valor de los estudios hechos en el colegio de jesuitas de La Habana, con motivo de una solicitud que remitió don José Pelligero y Serrano pidiendo abono de dos cursos de latinidad que hizo allí y pasar a tercero de aquí. La contestación fue afirmativa. 
que a su cargo se hallaba en La Habana, en que pudiesen estudiarse los cursos de la Facultad de Filosofía, partió del Ayuntamiento de la villa, el cual cedió para colegio el convento de San Francisco, que en aquella fecha no tenía utilidad alguna y era de su propiedad. Los gastos de instalación pudieron costearse gracias a la sıc. cripción de varios padres de familia. Los jesuitas de La Habana estaban conformes con hacerse cargo de la enseñanza en aquel centro siempre y cuando a la nueva Casa-Colegio se le declarase Congregación y se le asignasen los derechos correspondientes, por considerar no ser suficientes los recursos ofrecidos por la población para el sostenimiento de los religiosos. El 25 de julio de 1863 la Corte accedía a esta solicitud, declarándoles Congregación, por lo cual se le pedía al gobernador de la isla que formara el presưpuesto de las pensiones que se le debían de señalar, del fondo de bienes de Regulares, a los padres jesuitas de Sancti Espíritus.

En el Plan de Estudios elaborado para el centro dedican una mayor atención a la enseñanza secundaria, tanto a la elemental (tres cursos) como a la superior (cuatro cursos), especificando año por año las materias de estudio. En cuanto a la docencia de las primeras letras, en dicho Plan, sólo la incluyen como una especie de anexo de la secundaria, haciendo constar, con el epígrafe de Estudios Preparatorios que

"Además de los estudios indicados (segunda enseñanza) se ha establecido un curso preparatorio en favor de aquellos alumnos que al ingresar en el colegio carecieran de la suficiente instrucción para cursar inmediatamente y con frutos los estudios clásicos. Esta escuela preparatoria se divide en dos secciones».

Las materias de enseñanza de cada una de las dos secciones cran:

- Primera sección: doctrina cristiana, leer, escribir, primeras nociones de aritmética y geografía, rudimentos de gramática y parte de la Historia Sagrada.

- Primera sección: doctrina cristiana; catecismo del padre Ripalda, todo entero; de la gramática castellana, la primera 
parte o analogía; de Historia Sagrada, el compendio de Fleuri, todo entero; de aritmética: sumar, restar, multiplicar y dividir números enteros y nociones sobre quebrados; geografía, de la isla de Cuba. ${ }^{114}$

Como veíamos anteriormente, al hablar de los escolapios, el arzobispo de Cuba, Antonio María Claret, en informe solicitado por el general Concha, opinaba que tan pronto como se pudieran extender los jesuitas, además de su colegio de La Habana, se debían de hacer cargo de los seminarios conciliares «singularmente del de Cuba», con objeto de formar buen clero «que tanto se necesita en esta isla», concluía afirmando el prelado. ${ }^{115}$

C) Monasterios de religiosas

URSULINAS

\section{1.-Ursulinas en La Habana}

A lo largo del siglo XVIII varias bulas prohibieron que en los conventos de religiosas, hubiera mujeres seglares; para evitar la relajación de costumbres se ordenaba, desde Roma, que no se admitieran ni siquiera niñas para ser educandas, ni aun criadas.

Frecuentes fueron las instancias que, familias distinguidas

114 A.H.N., Ultramar, 66, núm. 12. Carta del gobernador, Francisco Serrano, al ministro de la Guerra y Ultramar. La Habana, 15 de octubre de 1862. Da cuenta de la creación del colegio de segunda enseñanza en Sancti Espíritus, a cargo de los jesuitas.

El 21 de abril de 1863, el nuevo gobernador de La Habana, Domingo Dulce, elevaba a la aprobación real el reglamento que había de regir el colegio, en el cual se habian adoptado las mismas reglas que para el de Belén de La Habana. Consta en el Plan, además de las materias de primera y segunda enseñanza, otros «estudios accesorios y de adorno»: lenguas inglesa y francesa, dibujo, música, declamación y equitación.

115 A.H.N., Ultramar, 50, núm. 1. Expediente sobre creación de una Escuela Normal. Carta del arzobispo de Cuba, Antonio María Claret, al gobernador de La Habana. 6 de abril de 1857. 
de La Habana, elevaron a la Corte, en las que exponían que deseaban educar, a sus hijas en el monasterio de Santa Clara; que para el numeroso vecindario de dicha ciudad era necesario dar «el consuelo de una buena educación Christiana y política para la juventud femenina de clase ilustre $y$ honesta...»; que no habiendo colegios con este destino convendría recurrir a la Santa Sede para que dispensase cualquier obstáculo que se opusiere a la admisión de educandas; que si este medio, extensivo a los otros dos conventos de dominicas y carmelitas descalzas que había en La Habana, pareciere inadaptable o insuficiente, por el aumento constante de población, pudiera fundarse un colegio de educación o un convento de ursulinas, tomando ejemplo del de Nueva Orleans. ${ }^{116}$

Las aspiraciones de la sociedad habanera pudieron verse cumplidas, a comienzos del siglo XIX, gracias a la cesión hecha por España de La Luisiana a Francia. El 24 de octubre de 1802, sor Antonia de Santa Mónica, superiora del convento de ursulinas de Nueva Orleans, solicitaba a la Corona que costease el real erario su traslado, así como el de otras ocho monjas españolas y algunas otras francesas ${ }^{117}$ a La Habana o a la capital de México, señalándoles igualmente una pensión. Consultado el Consejo de Indias, ${ }^{118}$ decidieron que se trasladasen y residiesen interinamente en alguno de los conventos de la capital de la isla cubana, hasta tanto informaran, el gobernador y el obispo, dónde serían más necesarias y útiles en el ejercicio de enseñar a la juventud de su sexo, y menos costase su establecimiento. ${ }^{119}$

116 A.G.I., Ultramar, 398. Consejo de Indias, 6 de noviembre de 1794. Dice ser frecuentes las instancias...

117 Teste, I.: Historia eclesiástica..., tomo IV, págs. 501-502. Las ursulinas que optaron por la salida fueron: Antonia Ramos (habanera), Margarita Dulievre de San Ignacio (asistenta francesa), Antonia del Castillo (habanera). Adelaida Dusuau de San Solano (francesa), Francisca Dusuau (francesa), Petrona Collazo de San Agustín (habanera), María Josefa Mirabal de San Miguel (habanera), María Ignacia Tera de Santa Clara (villaclareña), Isabel Vázquez de San Luis Gonzaga (villaclareña), Felicitas Carder de Santa Angela (irlandesa), María de Regla López de Santa Ursula (habanera), Genoveva Chimite de Santa Marta (francesa), María Jesús Sánchez de Santa Rosa (habanera), Morái de la Asunción Dourgue de Santa Rosalía (francesa) y Angélica Langine de San Estanislao (francesa).

118 A.G.I., Ultramar, 2. Consejo de 8 de junio de 1803.

119 A.G.I., Santo Domingo, 1.125-A. Desde la Corte se comunica al gobernador de La Habana que las religiosas ursulinas de Nueva Orleans se trasladan a la 
El 8 de noviembre de 1803 el gobernador, marqués de Someruelos, informaba a Madrid de la llegada a La Habana de la comunidad religiosa de la Luisiana; que de acuerdo con el obispo habían dispuesto que se hospedasen en los tres conventos de monjas que había en la ciudad. En cuanto a la pensión que solicitaban, se les señaló la misma que disfrutaban las monjas que fueron emigradas de Santo Domingo, es decir, 27 pesos mensuales a cada una. ${ }^{120}$

Numerosas dificultades encontraron para alojarse ${ }^{121}$ por estar los conventos muy poblados a consecuencia de las monjas procedentes de Santo Domingo. En febrero de 1804, la superiora de las ursulinas, solicitaba por medio de carta al Consejo de Indias se les hiciera donación, para establecer su convento, del colegio de Propaganda Fide, titulado de San Isidro, de los franciscanos, por estar sólo ocupado por dos o tres frailes. ${ }^{122}$

Por otra posterior carta de la superiora, sor Antonia de Santa Mónica, solicitaba se les. donara para su establecimiento la antigua Casa de Recogidas, titulada San Juan Nepomuceno, en la que se les había colocado provisionalmente, así como que se les asignara 20.000 pesos anuales sobre el fondo que colectaban para el vestuario de milicias, la Aduana y el Consulado de La Habana. ${ }^{123}$

La primera noticia que tenemos sobre su dedicación a la enseñanza nos la facilita su capellán, José Miguel de Moya. Después

capital de la isla de Cuba. Madrid, ¿1 de julio de 1803 . Folio 123 y siguientes. Con esa misma fecha se le informa de lo mismo al obispo (folio 132).

A.G.I., Santo Domingo, 1.127. Real cédula al obispo de La Habana, de 25 de julio de 1803 participándole haberse resuelto que las religiosas ursulinas de Nueva Orleans se trasladaban a aquella ciudad.

120 A.G.I., Ultramar, 398. Llegaron a La Habana el 23 de junio de 1803 por la tarde y se alojaron: seis en el monasterio de Santa Teresa, seis en el de Santa Clara y las cuatro restantes en el de Santa Catalina.

121 Ibídem. Carta del obispo al Consejo. La Habana, 5 de enero de 1804. Da cuenta de haberse pasado dichas religiosas a la Casa de Recogidas, con la correspondiente separación y proponiendo que se las coloque en el colegio de niñas de San Francisco de Sales.

122 Ibídem. El 5 de febrero de 1804, también solicitaba la posesión contigua al convento de San Isidro, nombrada el Palenque, que estaba habitado por algunos negros al servicio de la Artilleria.

" 123 Ibídem. La Habana, 28 de marzo de 1806. 
de exponer la crítica situación de mendicidad en la que se hallaban, sin contar con otros medios de subsistencia que los 27 pesos señalados, y reducidas a una habitación que sirvió de cárcel para mujeres, decía, dicho capellán, que eran acreedoras a la mayor atención por el mérito que contraían al educar a 136 discípulas exteriores y 50 entre pensionistas y pretendientes al hábito. Por ello solicitaba se les concediera la propiedad de la finca, los 20.000 pesos sobrantes del vestuario de milicias, por seis ocasiones, y dar hábitos siempre que tuvieren ocasión, con lo que evitarían ser gravosas al erario y al pueblo. ${ }^{124}$

Por los informes favorables, tanto del capitán general como del prelado de La Habana y del Consejo de Indias, en 1811, una real cédula mandaba al Ayuntamiento de La Habana que hiciese cesión absoluta y gratuita de la casa de San Juan Nepomuceno a las monjas ursulinas emigradas de Nueva Orleans, subrogando el importe de los alquileres en algún ramo de sus propios y arbitrios. Igualmente ordenaba, que para la construcción del coro, extensión de la capilla y acomodar todo el edificio, se les contribuyera cada año, por espacio de diez, con 8.000 pesos de los 20.000 sobrantes del vestuario de milicias y que se les permitiera recibir novicias. ${ }^{125}$

Pero todavía pasarán unos años para que mejore la situación de estas religiosas: la posesión definitiva de la casa de San Juan Nepomuceno no la tuvieron hasta diciembre de $1815 ;{ }^{126}$ del fondo

124 Ibídem. La Habana, 23 de junio de 1809.

125 A.G.I., Ultramar, 398 y Ultramar, ¿. El informe del capitán general y del obispo se pidió en 31 de octubre de 1809. Informe también favorable del flscal, fechado en Cádiz el 29 de enero de 1811. Informe del Consejo de 22 de febrero de 1811. Real cédula de 21 de abril de 1811.

126 A.G.I., Ultramar, 398. El capellán de las ursulinas, José Miguel de Moya, dice que le ha comentado el gobernador que los regidores no podían dar lo que no era suyo; que la Casa de Recogidas era de los obispos y que una real orden anterior expresaba que no debía tener otro destino que el de reclusión. La Habana, 5 de febrero de 1812. Al gobernador de La Habana se le ordenó, en 4 de junio de 1812 y 13 de diciembre de 1814, que manifestara los motivos para no dar cumplimiento a la real cédula de 21 de abril de 1811 . Por fin, el 12 de enero de 1816, el gobernador de La Habana daba cuenta de haber puesto en posesión de las ursulinas la Casa de San Juan Nepomuceno.

A.G.I., Santo Domingo, 2.241. José Miguel de Moya, solicita a la Corte, el 30 de julio de 1815 , que se les asigne a las ursulinas uno de los dos hospicios: 
sobrante del vestuario nunca recibieron nada, por no haber sobrante alguno en el mencionado fondo de La Habana; ${ }^{127}$ y sobre la concesión de hábitos, el obispo, Juan José Díaz de la Espada, había manifestado a las monjas que no se lo permitiría hasta que el convento tuviese suficientes medios económicos para que las aspirantes entrasen sin dote. ${ }^{128}$

La superiora de las ursulinas, en 1813, recurría a la Diputación Provincial de La Habana para informar de su situación. Exponía que era imposible continuar como hasta entonces porque habían fallecido los bienhechores que prodigaban sus auxilios y ellas habían consumido sus fondos; que sólo eran 15 religiosas, «las más de edad y casi todas de salud achacosa»; que era im-

el de San Felipe Neri o el de San Isidro (especialmente el primero), ocupados, por capuchinos el primero y el segundo por franciscanos, ambos en muy corto número.

A.G.I., Santo Domingo, 1.¿87. El capitán general, Apodaca, a Miguel de Lardizábal y Uribe (Ultramar), La Habana, 11 de octubre de 1814. Expone el estado en que se hallaba el establecimiento de las monjas ursulinas, proponiendo se les dé el Hospicio de San Isidro de misioneros franciscanos. Dice ser personas «extremadamente recomendables» y que mejor establecidas su beneficio sería mayor.

1¿7 A.G.I., Santo Domingo, 1.289. Apodaca a Miguel de Lardizábal. La Habana, 6 de mayo de 1815. Contesta a la real orden sobre señalamiento de alguna cantidad a las ursulinas del sobrante de vestuario de milicias. Contesta que con sentimiento suyo, del expresado fondo, nada se les puede señalar, por no habar sobrante alguno. El rey mandó de nuevo, que se les auxiliara con lo que fuera.

A.G.I., Uiltramar, 398. En 13 de enero de 1816. José Miguel de Moya, exponía a la Corona que «como jamás se cumplen en estos países tan remotos en un todo las soberanas disposiciones, por lo lexos y lo difícil de los recursos», se previno que se les diera 8.000 pesos, durante 10 años, no se habia verificado... por el pretexto de que no hay dinero. «Por las diligencias del Sr. intendente se informará V. M. de los fondos que han entrado para el empedrado de la ciudad y de lo que anualmente sobre después de vestidas las milicias». Suplicaba, el administrador, recibir los 8.000 pesos directamente de la administración de la Aduana, sin inter vención del Ayuntamiento, porque de lo contrario jamás obtendría nada.

128 A.G.I., Ultramar, 398. José Miguel de Moya, capellán de las ursulinas. el 5 de febrero de 1812, expresaba que tenían que correr muchos años y acaso siglos antes de que pudiera reunirse la masa suficiente para que se colocasen sin dote; que era muy difícil encontrar un capital de 200.000 pesos que rindiese 10.000 al año para su congrua manutención, todo lo cual se subsanaba con que se' les permitiese admitir novicias que pagasen a su entrada 3.000 pesos, «no sienda exorbitante el rendimiento de 150 pesos anuales para la manutención de una persona en un país donde son tan caros los viveres y renglones de primera necesidad».

Consejo de 27 de mayo de 1812. Cartas acordadas al gobernador y obispo de La Habana para que manifiesten los motivos para no dar cumplimiento a lo mandado. 
posible educar, por ellas solas, a 45 niñas internas y a 146 externas; que necesitaban criadas para el servicio y pretendientes del hábito con quien compartir el trabajo de la enseñanza; que si se quería perpetuar en La Habana el beneficio de la educación en las niñas, era indispensable que se realizara lo más pronto posib!e la asignación de una cantidad que estimaran suficiente para cubrir sus necesidades. Promover la educación de la juventud del sexo femenino, según dicha superiora expone en este documento, es

(c...tan interesante al bien público cuanto es poderoso el influjo que las mujeres han tenido siempre en las deliberaciones de los hombres). ${ }^{129}$

Sabemos, por la carta anteriormente mencionada de la superiora a la Diputación, que la enseñanza de las externas se hacía «enteramente de gracia» y que las internas abonaban una pequeña pensión que «ni era exacta ni segura la paga».

En agosto de 1814, viendo la superiora que no recibía «providencia alguna» de la Diputación, recurría a la Corona suplicando alguna atención. Alegaba como méritos contraídos, los diez años dedicados a la enseñanza (podemos considerar, por tanto, que desde 1804 tuvieron escuelas de niñas). En este nuevo documento, sor Antonia de Santa Mónica, exponía el programa de actividad escolar, tanto a las niñas que se educaban en el claustro como a las de clase externa:

(c...haciéndolas levantar a las 5 y $1 / 2$, de asistir con ellas a su oratorio para hacer el ejercicio cuotidiano, después ir con ellas al coro para oír misa hasta las 7 , el dirigir sus plumas sobre el papel de 8 a 9, de instruirles en la doctrina cristiana de 9 a 10 , de trabajar con ellas en las costuras, bordando, y en otros trabajos de su sexo según su capacidad y voluntad de sus padres, de 10 a 12 ; de 1 a 2 enseñar la aritmética; de 2 a 3 rezar el

129 Ibídem. Sor Antonia de Santa Mónica al Sr. presidente e individuos de la Diputación de esta provincia. La Habana, 23 de julio de 1813. 
rosario de María Santísima y Letanías; a las 3 volver, con unas a la labor, otras a la lección, otras a la gramática y ortografía castellana hasta las 5 que van a hacer oración al coro, y para cerrar el día, a las 7 y $1 / 2$ el ejercicio cuotidiano...). 130

El capellán de la Casa de Recogidas de La Habana, Joaquín de Pluma, en 1825, solicitaba a la Corte que se le devolviera a la institución que él administraba la casa que ocupaban las mon-1 jas ursulinas. ${ }^{131}$ Exponía el capellán que todo había ido bien, desde que se estableció la Casa de Recogidas, en 1746, hasta 1805 en que, por disposición de las autoridades, fueron colocadas en dicha casa las ursulinas, trasladando a las mujeres recogidas a otra de dimensiones más reducidas; y que no contentas todavía las religiosas con la posesión interina de la casa, solicitaron y obtuvieron la propiedad de ella por real cédula de 21 de abril de 1811; igualmente expresaba, dicho administrador, los 2.000 pesos que del fondo de vestuario de milicias se les había asignado a las recogidas, por vía de indemnización por el perjuicio que se les causaba. El capellán suplicaba que se ordenase resarcir de los perjuicios originados al establecimiento, con el abono del total del valor de dicha casa y de los alquileres vencidos, con el fin de poder proporcionar otro edificio a propósito para las recogidas. ${ }^{132}$

130 A.G.I., Santo Domingo, 2.241. Sor Antonia de Santa Mónica a S. M. La Habana, 8 de agosto de 1814.

131 A.G.I., Ultramar, 398. Exponía, dicho capellán, el 10 de junio de 1825 , que desde que se estableció la Casa de Recogidas, en 1746, todo fue bien hasta 1805 en que se colocaron en la citada casa las ursulinas, trasladando a las mujeres recogidas a otra de dimensiones más reducidas. Como medio de indemnización de los alquileres de la casa que se les despojaba, se ordenó que del sobrante del ramo de Vestuario de Milicias se les diera 2.000 pesos. En la consulta que la Regencia había hecho al Consejo para la cesión de la casa, ésta fue favorable a las monjas, por su utilidad, por lo que se les concedió el 21 de abril de 1811.

132 A.G.I., Ultramar, 5 y Ultramar, 398. La real cédula de 21 de abril de 1811 no fue cumplida por el gobernador ni el prelado de La Habana; sin embargo, el Ayuntamiento, en cabildo de 29 de agosto de 1811, acordó que debíai obedecerse en atención a que la Casa de Recogidas se formó con limosnas de particulares que deseaban la mejora de costumbres, y que era justo que recayese este beneficio en las monjas por el corto número de recogidas y ser todas ellas delincuentes, las cuales podrían pasarse a una de las cárceles, en donde estarían con más seguridad y causando menos costo. 
La resolución de la Corte fue pedir nuevos informes al capitán general, obispo y Ayuntamiento, por si el tiempo transcurrido hiciere necesario cambiar a las monjas de la referida casa, así como si convendría resarcir a las recogidas del valor de ella o si era bastante la renta que tenían. El gobernador, en carta de 29 de agosto de 1829, manifestaba que para hacerlo convenía citar a una Junta de autoridades, lo que había realizado, el 13 del mismo mes, y en la que habían acordado mejorar a la Casa de Recogidas, con cantidades que en el acto ofrecieron el obispo, el intendente y los comisarios del Ayuntamiento. ${ }^{133}$

Constantes fueron los clamores de falta de recursos por parte de las religiosas ursulinas. Uno más fue el 7 de enero de 1833 en el que pedian que, en atención a no haber tenido efecto' los arbitrios que se les destinaron en 1811 y órdenes posteriores, se mandara ahora que de los espolios del obispo Espada se les destinara alguna cantidad que fuera suficiente para ensanchar su convento. El informe de la Contaduría fue que esta gracia sólo podría tener efecto después de que el real erario se hubiese reintegrado de las sumas adelantadas con motivo de la epidemia de cólera. ${ }^{134}$

En el caso que nos ocupa, como resumen final, vamos a sacar algunas conclusiones. Percibimos, en primer lugar, una clase social favorecida por la instalación de las ursulinas, al contar con un centro de confianza para la enseñanza de sus hijas; en el punto opuesto hallamos un grupo minoritario, marginado, en el que al menos hay una duda razonable de atropello de sus derechos. Como segunda conclusión afirmamos que no se debe considerar a las religiosas como beneficiarias de esta situación porque en realidad ellas cumplían con su trabajo $\mathrm{y}$, sin embargo, desde que llegaron a la isla, como manifestaba el intendente de La Habana, vivían con suma estrechez, en un edificio insuficiente y mezquino, a pesar de lo cual habían sostenido además de sus funciones religiosas una educación con el mayor provecho y utilidad del «sexo

133 Ibídem.

134 Ibíden. Informe de la Contaduría, de 27 de septiembre de 1833. 
débil» eran dignas de la piedad del rey —seguimos resumiendo la opinión del intendente-, porque no tenían renta alguna cuando otras poseían las más pingües y eran dueñas de habitaciones cómodas (aquí se puede detectar una crítica solapada a teresas, catalinas y monjas de Santa Clara); y pone el dedo sobre la llaga, en el punto final, cuando expresa que en lugar de librar su existencia (las ursulinas) sobre aquellas Cajas Reales, muy recargadas, debía recaer «sobre algunas clases de la sociedad que nada contribuyen a los gastos del Estado y disfrutan de un bien real». ${ }^{135}$ Consideremos, en tercer lugar, que las autoridades no locales de la isla - gobernador, obispo, intendente-, tienen parte de culpa por dejarse arrastrar por los regidores de La Habana y no saber proponer mejores medidas. Por último, el Gobierno de Madrid, desconocedor en gran medida de lo que pasaba en Ultramar, siempre pretendía arreglar las cosas lo mejor posible, bajo los informes que recibía de allí. En algunos casos aprobó medidas después de hechos consumados, para evitar males mayores si llevaba la contraria a las autoridades locales.

\section{2.-Las Ursulinas en Puerto Principe}

La fundación del monasterio de las Ursulinas en Puerto Príncipe se debe, en principio, al presbítero de la villa, José Ceferino Alvarez, quien en 1816 exponía a la Corte que contando con más de 50.000 almas, no había convento de religiosas donde pudieran consagrarse «las vírgenes devotas que voluntariamente anhelen el claustro», ni un colegio para la educación de jóvenes «principalmente de las personas de más alta jerarquía... que formen mujeres completas para el estado religioso o ya para el matrimonio». Solicitaba que de la fundación de Santa Angela de Merici, o monjas ursulinas que se habían establecido en La Habana, pasaran cuatro a Puerto Príncipe para erigir otro monasterio bajo

135 Ibídem. Consideraba el intendente que se les podría dar el hospicio de San Isidro, que estaba ocupado sólo por dos franciscanos y era espacioso, sin gravamen del real erario. 
la advocación de Nuestra Señora del Carmen. Apoyaba el sacerdote su petición en otras circunstancias: primera, que aunque hubiera el mismo convento en La Habana, además de ser las dotes crecidas, había que emprender un largo viaje de cerca de 200 leguas, que llevaba consigo gastos, incomodidades y otros perjuicios como el sentimiento de padres y parientes de alejar a tanta distancia a sus hijas; segunda, que otros pueblos cercanos a Puerto Príncipe tenían el mismo interés; tercera, que muchas jóvenes se hallaban con ardientes deseos de entrar en clausura, con sus correspondientes dotes de 2.000 pesos; cuarta, que había un elevado número de pudientes en dicha villa que estaban dispuestos a contribuir con cantidades considerables para la reedificación de un monasterio con su iglesia y todas las dependencias necesarias, sin que el erario tuviese que exponer cantidad alguna.

Curioso es el informe del fiscal de Nueva España, con respecto a este asunto. Exponía que no sólo lo recomendaba por útil sino que lo apoyaba aquel Ayuntamiento y cuantos declaraban como testigos en la información sumaria; que convenía «evitar dilación... por el miedo de que se resfríen los ánimos en un asunto de tanto interés espiritual y temporal». Siendo favorable tanto la opinión del fiscal como la del Consejo de Indias, una real cédula de 21 de mayo de 1817, dirigida al arzobispo de Cuba, le encargaba que de acuerdo con el capitán general de la isla procediera a erigir en Puerto Príncipe un monasterio de ursulinas. ${ }^{136}$

El 15 de agosto de 1817 la comunidad religiosa de Santa Ursula de La Habana estaba reunida con el fin de elegir a las cuatro compañeras que habían de desplazarse a Puerto Príncipe, para cum-

136 A.G.I., Ultramar, 3. Carta del teniente gobernador de Puerto Príncipe a la Gobernación de Ultramar. 21 de marzo de 1816. Acompaña un testimonio de las diligencias practicadas por don José Ceferino Alvarez, presbítero de la villa, y a instancias y consentimiento de diferentes vecinos, con objeto de acreditar que en aquel pueblo hay necesidad de un monasterio de monjas. El 10 de agosto de 1816 repitió Alvarez su instancia, por medio de apoderado.

A.G.I., Ultramar, 398. Josef Ceferino Alvarez, presbítero... a V. M. (Como apoderado firma Lorenzo Cisneros y Toledo). Madrid, 10 de agosto de 1816. El informe del fiscal fue de fecha 15 de enero de 1817 y el del Consejo de 4 de febrero del msimo año. 
plir la disposición soberana, que acababan de recibir de manos del arzobispo de Cuba. ${ }^{137}$

Pero veamos otros hechos ocurridos en la villa y que tienen relación con esta fundación. En julio de 1794 había hecho testamento el capitán don Lorenzo de Miranda, dejando a su mujer como única heredera usufructuaria con sus bienes un hospicio de mujeres pobres, recogidas en la casa de su morada, imponiéndose el resto de su capital en fincas, cuyo rédito sirviese para mantenerlas a ellas y al capellán que les administrase los sacramentos y dirigiese los rezos.

Como consecuencia de la real cédula de mayo de 1817 , de erección de las ursulinas, el vicario de Puerto Príncipe y el capitán general acordaron, el 10 de julio de 1818 , conmutar a favor de dichas religiosas la citada Obra pía, trasladándose las cuatro monjas ursulinas a la antigua casa del capitán Lorenzo de Miranda. ${ }^{138}$

Las quejas tardaron unos años en llegar; el 4 de marzo de 1825, el nuevo capellán de la Obra pía de Miranda, José Rafael Caballero, exponía a la Corona que «las preces para la fundación de las ursulinas fueron falsas $y$ aparentes las ofertas de los vecinos»; que de esta manera se había echado de la casa a las pobres recogidas, tratando de venderla y de oponerse al pago de la renta alimenticia del capellán, todo a la sombra de un indebida conmutación, por lo que pedía que se anulase la erección hecha, por no haberse cumplido las ofertas que la motivaron. Después de cinco años de abundantes informes y órdenes entre las autoridades de Cuba y las de Madrid, una real cédula de 23 de mayo de 1830 ponía

137 Teste, I.: Historia eclesiástica.... tomo IV, págs. 507-508. Se presentaron voluntariamente las cuatro, que resultaron ser: Sor Antonia del Castillo, María de Jesús Sánchez, Juana Conde - primera profesora de La Habana- y Josefa Espinosa. Salieron de La Habảna el 24 de marzo de 1819, siete días de navegación hasta Nuevitas, otros siete esperando carruaje y un día de viaje por tierra. Llegaron a Puerto Príncipe el 7 de abril de 1819.

138 Ibídem, tomo IV, pág. 508. Apoyándose en el informe que las monjas hicieron a su monasterio de La Habana, en el que dicen que la Casa de Beneficencia les estaba destinada para su fundación, expresa que en dicha Casa (de Beneficencia) permanecieron por espacio de diez años, en cuyo tiempo un sacerdote franciscano se ocupó de recoger limosnas y donativos para construir un edificio que correspondiera con las necesidades de las religiosas. Todo eso es incierto. 
punto final al asunto, desestimando la queja de Caballero y mandando que se llevara a efecto la conmutación de la Obra pía de Miranda. En esa fecha ya había sido vendida la casa del capitán benefactor y se había construido un nuevo monasterio, al que se habían trasladado en 1828 las monjas ursulinas. ${ }^{139}$

139 A.G.I., Ultramar, 398. La respuesta del fiscal, sobre la queja de Caballero fue de que se desestimase por no probar los hechos que denunciaba y que usase de los derechos que creyere asistirle donde y como debía.

El 27 de noviembre de 1826, el síndico de las ursulinas comunicaba a! Consejo de Indias, la necesidad y utilidad de ensanchar el establecimiento, vendiendo el edificio y fabricando otro más proporcionado; que el comprador no lo habría de ocupar hasta salir de él las religiosas para el ntevo, el cual se restituiría a la Obra Pía de Miranda en el caso remoto de dejar de existir el monasterio. Tanto' el metropolitano como el capitán general habían dado su visto bueno en of cios de 14 y 20 de febrero de 1826, por lo que hicieron tasar el edificio. El Consejo, el 5 de marzo de 1827, acordó se dijese al capitán general que para la nueva edificación debían contribuir los vecinos que se ofrecieron a ello; que la fundación de la Casa de Mujeres también era conveniente y se debía de llevar a cabo. De acuerdo con este informe se expidió la real cédula de 27 de abril de 1827.

El capitán general, en 10 de diciembre de 1827 oflció al jefe político de Puerto Príncipe y al arzobispo de Cuba para que adoptasen las menidas conducentes a llevar la voluntad de la Corona. El prelado contestó, el 16 de enero de 1828, que veía con amargura que el capellán, de mala fe, había sorprendido el real ánimo, faltando a la verdad en unos puntos y silenciando otros, pues estaba claro que era imposible de subsistir la Obra pía de Miranda. El informe del teniente de gobernador de Puerto Príncipe, de 12 de febrero de 1828, manifestaba que del nuevo monasterio se hallaba enteramente construida la iglesia, y provista de altares, ornamentos, vasos sagrados y todo lo demás; que antes de diciembre de aquel año 1828- se finalizaría con sus claustros y salas de enseñanza.

Como presidente de la Junta de Beneficencia, también informaba, que la Casa llamada de Recogidas, a pesar de sus desvelos y los de sus vocales, jamás progresó por falta de medios, que la misma Junta había recomendado su conmutación a favor de las ursulinas, por considerar que en su clausura cumplían con los ejercicios de piedad y devoción ordenados por Miranda, además de la enseñanza. También decía que era falso se hubiera quedado en meras promesas los of recimientos de los vecinos, pues intimados por la real licencia no reconocieron tal obligación, por haber sido voluntaria; no obstante estaban dispuestos a contribuir con liberalidad en materiales, operarios y dinero. Esta autoridad exponía que era imposible que ambas instituciones progresasen a la vez.

El presbitero Caballero, renovando sus quejas, volvió a recurrir a la Corona pidiendo que se cumpliera la real cédula de abril de 1827, o que se le oyera como representante de Miranda, su tío.

El 13 de febrero de 1829 , las cuatro monjas ursulinas firmaban un Memoria! en el que exponían a la Corte que confiaban en que fuese segura su subsistencia. que por eso pasaron de La Habana. Pedían se aprobara lo hecho.

El Consejo en Pleno, de 20 de abril de 1830, de acuerdo con el informe del fiscal, de 8 de marzo, fue de parecer que se llevara a efecto la conmutación. y de que se le pagara al capellán (Caballero) las cantidades que se le debían, pero con la obligación de asistir, como tal capellán, al convento de ursulinas, y si se sentía perjudicado que recurriera judicialmente (en el Trienio Liberal le habían' 
Hemos encontrado pocos documentos que nos manifiesten el número de alumnas que pasaron por las aulas de estas religiosas. El síndico de las ursulinas, comisionado por el teniente de gobernador para llevar a efecto la erección, nos dice que una vez reparada la casa de la Obra pía, se colocaron en ella las monjas, obteniendo la población muchas ventajas de su enseñanza, «acudiendo gran número de niñas» (sin decir cuantas). ${ }^{100} \mathrm{De}$ diez años después -1828 - tenemos un dato algo más explícito pero todavía incompleto; el teniente de gobernador imformaba «que además de las educandas pensionistas ( $₫$ ?) había 60 externas» y que cuando se finalizasen las obras del claustro y de las salas de enseñanza se podría admitir mayor número, tanto de internas que solicitaban el hábito como de externas. ${ }^{141}$ Efectivamente debió de ser así, porque en la Memoria que al siguiente año - 1829- elevaba Joaquín de Miranda y Madariaga al rey, le exponía que contaba con: 4 monjas, 4 postulantes, 5 pensionistas, 108 educandas, 1 capellán, 1 síndico y 1 vicesíndico. ${ }^{142}$

Al tener mayor amplitud en el nuevo monasterio la comunidad amplió considerablemente sus efectivos. En la relación de bienes de los regulares, de 1837, en la ya ciudad de Puerto Príncipe, profesaban 16 monjas de Santa Ursula, teniendo a su cargo, como siempre fue habitual en ellas, una escuela gratuita de primeras letras. ${ }^{143}$

subido de 125 a 200 pesos). Este informe del Consejo dio lugar a la real cédula de 23 de mayo de 1830, que ordenaba se llevase a efecto la conmutación.

A.G.I., Ultramar, 6. Consta en este legajo otro expediente sobre la conmutación de la obra pía de Miranda en favor de las ursulinas. La casa de Miranda' se tasó en 15.084 pesos. El Consejo, al proponer la conmutación, tuyo presente el ofrecimiento que había hecho el regidor de Puerto Príncipe, don Graciand de Betancourt, de donar una casa de 25.000 pesos de valor, para establecer una Casa de Expósitos, de asilo de mujeres mendigas y de corrección de otras, con objèta. también de que se ocuparan en la asistencia del hospital contiguo. Las miras de Miranda, según el Consejo, quedaban suplidas con mayores ventajas.

140 A.G.I., Ultramar, 398. El síndico de las ursulinas al Consejo. 27 de noviembre de 1826.

141 A.G.I., Ultramar, 6 y Ultramar, 398. Informe del teniente de gobierno de Puerto Príncipe, en cumplimiento de la cédula de 27 de abril de 1827. Puertor Príncipe, 12 de febrero de 1828.

142 A.G.I., Santo Domingo, 1.157. Memorias de don Joaquín de Miranda' y Madariaga al rey. Madrid, 1829. 
Se puede observar cómo tanto en La Habana como en Puerto Príncipe, la instalación de las monjas ursulinas se hizo atropellando, en cierta medida, los derechos adquiridos por otros grupos sociales marginados, con la aprobación de las autoridades locales. Los regidores de ambas capitales se preocuparon más de los intereses de la élite, por ser los suyos propios, que de los de la mayoría de la población. Trataron de beneficiar a una clase elevada, o al menos media, en perjuicio de los más menesterosos. Las conclusiones que poníamos, como resumen final de las ursulinas de La Habana, también pueden considerarse válidas para las mismas religiosas de Puerto Príncipe.

\section{Santa Clara (Franciscas)}

Como ya veíamos al hablar de las ursulinas, frecuentes eran las instancias de personas distinguidas de La Habana que deseaban educar a sus hijas en el monasterio de Santa Clara y no podían hacerlo por prohibirlo el Estatuto de la Orden. Carlos IV, ante esta situación, solicitó de la Corte de Roma que se dignase conceder la correspondiente facultad para que en el referido monasterio y demás conventos de religiosas de sus dominios de Indias fuesen admitidas a la educación las niñas de esas principales familias que lo deseaban. Condescendiente Su Santidad a las súplicas del monarca hispano expidió, en 21 de julio de 1795, un breve por el que habilitaba a los prelados de Indias para que pudieran dar licencia a las niñas «procreadas de padres honrados y decentes», de edad mínima de siete años para que pudieran entrar «en clase de educandas en el Monasterio de Santa Clara de La Habana, y en los demás Monasterios que respectivamente os estén sujetos...» permaneciendo en ellos hasta que quieran casarse, tomar el hábito o que cumplan 25 años, precedido el beneplácito de la Comunidad por votos secretos, sin llevar criadas, usando de vestido y adorno mode-

143 A.G.I., Santo Domingo, 1.306. Resumen de los bienes que poseen los regulares de la isla de Cuba. 12 de septiembre de 1837. 
rado, observando las reglas de locutorio y clausura y pagando lo que dichos ordinarios establecieren. ${ }^{144}$

Estamos ante la comunidad religiosa mejor dotada de La Habana, la que contaba con mayores rentas. Toda la clase «ilustre» pretendía llevar a ella a sus hijas con objeto de que adquiriesen «una buena educación cristiana y política». Ella fue la que motivó el breve que hemos mencionado anteriormente.

Pero dos causas influyeron para que, a pesar de contar con la licencia papal, no se llevara a cabo la admisión de educandos: primera, la paz de Basilea - 1795- por la que España cedía a Francia la mitad de la isla de Santo Domingo hizo que varias religiosas, de la misma orden, franciscanas observantes, se refugiaran en el monasterio de Santa Clara, ocupando hasta el último rincón de sus dependencias; ${ }^{145}$ segunda, el traslado de las ursulinas de Nueva Orleans a La Habana - 1803_, vendría a llenar la falta de enseñanza de niñas que la población demandaba.

Tan sólo tenemos noticias de su dedicación a la docencia durante 1819, a raíz de la orden de Fernando VII de impartir clases gratuitas en los claustros de conventos y monasterios.

\section{OTROS MONASTERIOS DE RELIGIOSAS}

El monasterio de Santa Catalina, poblado por monjas dominicas, fue fundado en La Habana en 1658. Aunque como hemos

144 A.G.I., Santo Domingo, 1.155-A. Consta en este legajo el breve pontificio de 21 de julio de 1795 y la real cédula dirigida a los virreyes del Perú y .Nueva' España, presidentes de reales audiencias y gobernadores, ordenando se comunicase (el breve) para su observación. San Lorenzo, 26 de diciembre de 1795.

145 A.G.I., Ultramar, 396, 398, 132 y Santo Domingo, 2.241. El convento tenía 65 celdas. Antes de la llegada de las 24 monjas, con sus respectivas criadas, emigradas de Santo Domingo, ya estaba lleno, por lo que se reunieron un excesivo número de mujeres - -11 i en total--. Para reducir el número de religiosas decidieron no admitir más que una novicia por cada tres que faltaren (si no admitían ninguna la población del monasterio no contaría con gente joven necesaria para determinadas labores), hasta llegar a 65 que era el número de celdas. En 1837 se había reducido la población del monasterio a 39 monjas profesas.

En 1815 habían solicitado ampliar el número a 70,50 monjas de velo negro y 20 legas, para el servicio del convento, y así tener que evitar la necesidad de tener criadas seglares. 
visto, al hablar del de Santa Clara, por el breve de Su Santidad de 1795 podían admitir educandas, con licencia del prelado, no nos consta que se dedicaran a la enseñanza, si exceptuamos. la formación de las novicias que entraban en su orden y la escuela gratuita para niñas de La Habana que en enero de 1810 se abría en este convento, en cumplimiento de lo mandado por el monarca en octubre de $1817 .{ }^{146}$

En cuanto al monasterio de Santa Teresa, de carmelitas descalzas, fue fundado en La Habana en 1702. Igual que hemos comentado al tratar del convento de catalinas, no tenemos, dato alguno que nos permita asegurar que las monjas carmelitas impartieran otro tipo de enseñanza que en las excepciones apuntadas anteriormente.

Respecto a las Hermanas de la Caridad o Hijas de San Vicente sabemos que, en enero de 1847 , seis de sus miembros llegaron a La Habana y que inmediatamente se pusieron al frente de las escuelas de niñas y salas de mendigos de la Real Casa de Beneficencia. El cuidado de los niños expósitos fue el motivo de su llegada a la isla de Cuba, aunque luego ampliaron su campo de acción a otras actividades como la enseñanza. ${ }^{147}$

Testimonios laudatorios de la actividad pedagógica de estas religiosas los encontramos, pero ya en fecha posterior a nuestro estudio.

En el caso de las Misioneras Claretianas estamos ante la primera congregación nacida en esta isla antillana. Deben su fundación al arzobispo de Cuba, Antonio María Claret, hoy en los alta-

146 A.G.I., Santo Domingo, 1.342. Memorias de la Real Sociedad Económica de La Habana, núm. 24. 31 de diciembre de 1818. Educación pública en las casas religiosas.

147 Teste, I.: Historia eclesiástica..., tomo IV, págs. 523-524. Las seis hermanas eran: Casimira Irazogui, superiora; Benita Pérez; Eustaquia de Benito; Martina Iribarren; Agustina Cortés y María Juana de Lastiegui. Los padres paúles. Bosch y Vila, fueron sus capellanes. Se encargaron igualmente de una escuela de párvulos y de pobres para los residentes en el barrio inmediato al asilo y allí dieron pruebas, las Hijas de San Vicente, de su preparación pedagógica.

148 Ibidem, pág. 597. Las cinco jóvenes eran: María Antonia París, Florentina Seingler, Josefa Caixal y Rosa y María Encarnación Guall. 
res. Después de comprobar, el santo prelado, el abandono de la educación de la juventud, especialmente la femenina, decidió reformar los estudios en el seminario y atender a la instrucción de la juventud. Dentro de estas medidas de reforma hay que situar la creación de esta orden misionera.

El 26 de mayo de 1852 llegaban a Santiago de Cuba cinco jóvenes religiosos, ${ }^{148}$ que iniciaron su clausura y noviciado el 7 de junio de 1853, de acuerdo con las reglas dadas por el arzobispo. El 20 de noviembre de 1854, el prelado suplicaba a Su Santidad el Papa Pío IX, que permitiese erigir en la ciudad un monasterio de enseñanza en el cual se observarían sustancialmente las reglas de San Benito. El 16 de julio de 1855 se recibía en Santiago de Cuba la contestación de Roma, favorable a la solicitud de Antonio María Claret, procediendo posteriormente a recibir los votos las cuatro hermanas (Florentina Seingler había fallecido), y depositando el cargo de priora en la madre Antonia París de San Pedro. ${ }^{149}$

Para solidificar su obra, el arzobispo, pensó crear un noviciado en España. En Tremp, en 1859, quedó fundada la segunda Casa de la Congregación, que era, a su vez el noviciado.

Posteriormente se irán extendiendo (en el último tercio del XIX y en el siglo XX), por Baracoa, Palma Soriano, La Habana.

En mayo de 1818 se detuvieron en La Habana las primeras religiosas de una nueva congregación - la Sociedad del Sagrado Corazón-, las cuales se dirigían a los Estados Unidos. En 1854, monseñor Hugus -obispo de Nueva York-, por motivos de salud, pasó a la capital antillana y se puso en contacto con el prelado habanero -Fleix y Solans- los cuales trataron sobre la posibilidad de crear en esta ciudad, un colegio regido por la mencionada institución.

Después de solucionar algunos problemas que salieron al paso, el 19 de marzo de 1858, abrían el colegio, contando con 40 alumnas pensionistas. La casa fue colocada bajo el patrocinio del Purísimo Corazón de María.

149 Ibidem, pág. 598. 
Se suscitaron algunos problemas entre la comunidad, el obispo de La Habana y las autoridades civiles, por los recelos de dependencia de las religiosas de una madre vicaria, Hardy, que residía en el extranjero y era precisamente norteamericana. ${ }^{150}$

Gran parte del pueblo cubano - dice Teste-, ha calificado a estas religiosas de aristócratas, pero él justifica la idea que tenían de orientar las primeras fundaciones hacia las clases pudientes, porque tenían el doble objetivo de: formar a la clase dirigente para salvar el país y obtener medios, legítimamente adquiridos, para atender a los necesitados. Esta es la razón —insiste-, por la que junto a cada colegio se abrió una escuela gratuita.

\section{Angel Huerta Martínez}

150 Ibídem, págs. $606 \mathrm{y}$ siguientes. 